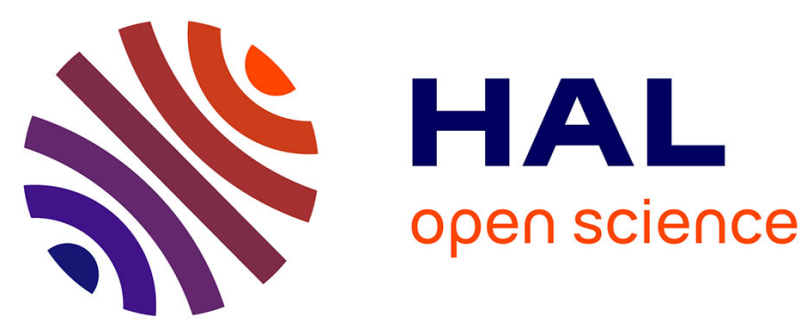

\title{
Gene Structure of the Kiss1 Receptor-2 () in the Atlantic Halibut: Insights into the Evolution and Regulation of Genes
}

Alejandro S. Mechaly, Jordi Viñas, Colleen Murphy, Michael Reith, Francesc

Piferrer

\section{To cite this version:}

Alejandro S. Mechaly, Jordi Viñas, Colleen Murphy, Michael Reith, Francesc Piferrer. Gene Structure of the Kiss1 Receptor-2 () in the Atlantic Halibut: Insights into the Evolution and Regulation of Genes. Molecular and Cellular Endocrinology, 2010, 317 (1-2), pp.78. 10.1016/j.mce.2009.11.005 . hal-00559592

\section{HAL Id: hal-00559592 \\ https://hal.science/hal-00559592}

Submitted on 26 Jan 2011

HAL is a multi-disciplinary open access archive for the deposit and dissemination of scientific research documents, whether they are published or not. The documents may come from teaching and research institutions in France or abroad, or from public or private research centers.
L'archive ouverte pluridisciplinaire HAL, est destinée au dépôt et à la diffusion de documents scientifiques de niveau recherche, publiés ou non, émanant des établissements d'enseignement et de recherche français ou étrangers, des laboratoires publics ou privés. 


\section{Accepted Manuscript}

Title: Gene Structure of the Kiss1 Receptor-2 (Kiss1r-2) in the Atlantic Halibut: Insights into the Evolution and Regulation of Kiss Ir Genes

Authors: Alejandro S. Mechaly, Jordi Viñas, Colleen Murphy, Michael Reith, Francesc Piferrer

PII: S0303-7207(09)00570-X

DOI: doi:10.1016/j.mce.2009.11.005

Reference: MCE 7369

To appear in: $\quad$ Molecular and Cellular Endocrinology

Received date: $\quad$ 5-8-2009

Revised date: $\quad$ 18-10-2009

Accepted date: $\quad$ 11-11-2009

Please cite this article as: Mechaly, A.S., Viñas, J., Murphy, C., Reith, M., Piferrer, F., Gene Structure of the Kiss1 Receptor-2 (Kiss1r-2) in the Atlantic Halibut: Insights into the Evolution and Regulation of Kiss Ir Genes, Molecular and Cellular Endocrinology (2008), doi:10.1016/j.mce.2009.11.005

This is a PDF file of an unedited manuscript that has been accepted for publication. As a service to our customers we are providing this early version of the manuscript. The manuscript will undergo copyediting, typesetting, and review of the resulting proof before it is published in its final form. Please note that during the production process errors may be discovered which could affect the content, and all legal disclaimers that apply to the journal pertain. 


\title{
Gene Structure of the Kiss1 Receptor-2 (Kiss1r-2) in the Atlantic Halibut: Insights into the Evolution and Regulation of Kiss 1r Genes
}

\author{
Alejandro S. Mechaly ${ }^{a}$, Jordi Viñas ${ }^{a, *}$, Colleen Murphy ${ }^{b}$, \\ Michael Reith ${ }^{\mathrm{b}}$ and Francesc Piferrer $^{\mathrm{a}}$
}

\footnotetext{
${ }^{a}$ Institut de Ciències del Mar, Consejo Superior de Investigaciones Científicas (CSIC), Barcelona, Spain.

${ }^{\mathrm{b}}$ Institute for Marine Biosciences, National Research Council (NRC), Halifax, Canada. *present address: Laboratori d'Ictiologia Genètica, Departament of Biology, University of Girona, E-17071, Girona, Spain.
}

Running title: Structure of Kiss 1r-2 in Hippoglossus hippoglossus

Funding information: A.S.M. was supported by a predoctoral scholarship from the Spanish Ministry of Education and Science (MEC)

Correspondence to: Dr. Francesc Piferrer, Institut de Ciències del Mar, Consejo Superior de Investigaciones Científicas (CSIC). Passeig Marítim, 37-49. 08003 Barcelona, Spain. Tel., +34-932309567; Fax, +34-932309555; E-mail: piferrer@icm.csic.es 


\begin{abstract}
Kisspeptin and its receptor, Kiss1r, play an essential role in the control of the onset of puberty in vertebrates. We characterized the cDNA and genomic DNA encoding Kiss1r in Atlantic halibut (Hippoglossus hippoglossus). The 1,146 bp open reading frame predicts a 381 amino acid protein with high homology to the Kiss1r-2 of other teleost fish. Phylogenetic analysis of Kiss1r sequences suggests that the mammalian Kiss1r-1 form arose by way of a gene duplication prior to the emergence of amphibians. Synteny analysis demonstrated the highly conserved nature of the $\underline{\text { Kiss } 1 r-2}$ region in teleosts, suggesting that flanking regulatory sequences are also likely to be conserved. Bioinformatic analysis identified six conserved regions in piscine $\underline{\text { Kiss } 1 r-2}$ upstream sequences, providing potential targets for future in-depth investigation of $\underline{\text { Kiss } 1 r-2}$ regulation. Kiss $1 r-2$ expression in the brain increased coinciding with the onset of puberty. Expression levels in the gonads were two orders of magnitude lower than those of the brain, a characteristic apparently conserved in other fishes, and expression in gonads was only detected in immature fish.
\end{abstract}

Keywords: Kisspeptin, $\underline{\text { Kiss } 1 r}$, Kiss-1 receptor, gpr54, puberty, Atlantic halibut. 


\section{Introduction}

Puberty is a cascade of developmental events that culminates in a mature adult reproductive system (Schulz and Goos, 1999). This process is regulated by a series of actions along the hypothalamic-pituitary-gonadal (HPG) axis in mammals (Ojeda, 2006) and fishes (Weltzien et al., 2004; Taranger et al., 2009). The hypothalamic neurons stimulate the production of the gonadotropin-releasing-hormone $(\mathrm{GnRH})$ which, in turn, activates the pulsatile secretion of two gonadotropins, follicle-stimulating hormone (FSH) and luteinizing hormone (LH) (Funes et al., 2003; Gottsch et al., 2004; Messager et al., 2005). A recently described system consisting of the peptide hormone kisspeptin and its receptor have been demonstrated to be crucial in the initiation of puberty in vertebrates (de Roux et al., 2003; Funes et al., 2003) by regulating the HPG. In mouse (Mus musculus) and rat (Rattus

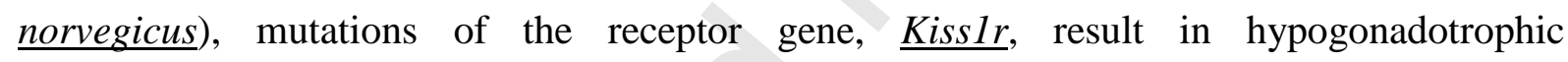
hypogonadism, a syndrome characterized by reduced secretion of gonadotropins, and subsequent abnormal pubertal development (de Roux et al., 2003; Seminara et al., 2003). Puberty regulation by the kisspeptin-Kiss1r system appears to be conserved in fish, amphibians and mammals (Roseweir and Mir, 2009).

The kisspeptin receptor (Kiss1r) was first identified in rat as an orphan G-protein coupled receptor (Lee et al., 1999). In 2001, the role of this protein as a receptor for kisspeptin was defined (Kotani et al., 2001; Muir et al, 2001; Ohtaki et al. 2001). This gene has been subsequently identified in many mammalian species, including human ( $\underline{\text { Homo }}$ $\underline{\text { sapiens) (Muir et al., 2001), mouse (Stafford et al., 2002), rhesus macaque (Macaca mulatta) }}$ (Shahab et al., 2005) and pig ( $\underline{\text { Sus scrofa }) ~(L i ~ e t ~ a l ., ~ 2008) ~ a m o n g ~ o t h e r s . ~ K i s s 1 r ~ c o n t a i n s ~}$ 
seven transmembrane domains (TMDs) that are highly conserved among species, a feature that facilitates the cloning of the Kiss 1 r in additional taxa. This approach has been used to clone $\underline{\text { Kiss } 1 r}$ in lower vertebrates including an amphibian, the bullfrog (Rana catesbeiana) (Moon et al., 2008) and several fishes: Nile tilapia (reochromis niloticus) (Parhar et al., 2004), cobia (Rachycentron canadum) (Mohamed et al., 2007), grey mullet (Mugil cephalus) (Nocillado et al., 2007), fathead minnow (Pimephales promelas) (Filby et al., 2007), zebrafish (Danio rerio) (Biran et al., 2008), Senegalese sole (Solea senegalensis) (Mechaly et al., 2009) and goldfish (arassius auratus) (Li et al., 2009). Additionally, $\underline{\text { Kiss } 1 r}$ has been identified in the genome sequences of other species including medaka ( $\underline{\text { Oryzias latipes }})$, three-spined stickleback (Gasterosteus aculeatus), pufferfish (Tetraodon nigroviridis), fugu (Takifugu $\underline{\text { rubripes }}$ ), clawed frog ( $\underline{\text { Xenopus tropicalis })}$ and the lesser hedgehog (Echinops telfairi $)$ (Lee et al., 2009; Mechaly et al., 2009).

Recently, a second form of kisspeptin, Kiss2, which shows amino acid differences in three positions compared to Kiss1, has been identified in non-mammalian vertebrates (Felip et al., 2009; Kitahashi et al., 2009; Lee et al., 2009). As well, multiple copies of $\underline{\text { Kiss } 1 r}$ have been detected in some species: two Kisslr are present in zebrafish, medaka (Lee et al., 2009),

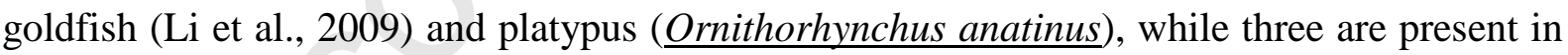
clawed frog (Lee et al., 2009). Amino acid similarity and synteny analyses suggest that two $\underline{\text { Kiss } 1 r}$ lineages ( $\underline{\text { Kiss } 1 r-1}$ and $\underline{\text { Kiss } 1 r-2})$ arose through gene or chromosome duplication with a second gene duplication occurring in the Kiss1r-1 lineage to produce the amphibian $\underline{\text { Kiss } 1 r \text {-1a }}$ and $\underline{\text { Kiss } 1 r-1 b}$ genes (Lee et al., 2009). Most fish $\underline{\text { Kiss } 1 r}$ characterized to date fall into the $\underline{\text { Kiss } 1 r-2}$ class (Mechaly et al., 2009). The two paralogous $\underline{\text { Kiss } 1 r}$ genes detected in zebrafish, named Kiss1ra and Kiss1rb, showed differences in their pattern of gene expression during 
maturation. Thus, while $\underline{\text { Kiss } 1 \mathrm{ra}}$ expression was higher during puberty and low in mature fish, $\underline{\text { Kiss Irb }}$ expression levels were consistent throughout these stages (Biran et al., 2008). Pleuronectiformes, along with the order Tetraodontiformes, constitute a modern and derived group of teleosts. With the limited information available so far, it seems that in these orders the ligand and its receptor, Kiss1r-1 have been lost during evolution, but this needs

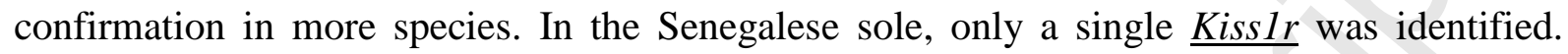
However, two different transcript variants were detected (Mechaly et al., 2009). The two variants (named Ss Kiss $1 r_{\_} v 1$ and $S s \underline{\text { Kiss } 1 r_{\_} v 2 \text { ) }}$ ) originated from a single gene by alternative splicing that involved retention of the entire intron III. The two isoforms of Senegalese sole also showed differences in their expression pattern: Ss Kiss $1 r_{\_} v 1$ had a higher expression than the Ss $\underline{\text { Kiss } 1 r \_v 2}$ in the brain while the opposite occurred in gonads (Mechaly et al., 2009). The different gene copies and isoforms of Kiss1r complicate the understanding of the roles of these genes in controlling the onset puberty in vertebrates. Whether the lack of two different genes in these fish is compensated by the appearance of splice isoforms is still not known.

Human KISS1R is expressed in many tissues, including placenta, pituitary, spinal cord pancreas, brain, stomach, intestine, thymus, spleen, lung, testis, kidney and liver (Kotani et al., 2001) suggesting pleiotropic functions for this system. In puberty regulation, the focus has been the brain and the gonads, two organs that play crucial roles in the control of maturation during different stages of development (Nocillado and Elizur, 2008). Expression of $\underline{\text { Kiss } 1 r}$ during development in fishes shows a variety of patterns. For instance, in the brain of Nile tilapia $\underline{\text { Kiss } 1 r}$ expression was associated with three GnRH neuron types (GnRH1, GnRH2 and GnRH3) (Parhar et al., 2004) and showed a significant increase of expression during gonadal maturation (Parhar et al., 2004). A similar pattern was observed in cobia, with an increase of 
mRNA levels of Kiss1r in the brain during the early stages of puberty (Mohamed et al., 2007). However, Kiss Ir expression in the brain of the grey mullet was elevated during early puberty but decreased during advanced stages (Nocillado et al., 2007). In the brain of fathead minnow, Kiss $1 r$ mRNA peaked before the onset of puberty and decreased thereafter (Filby et al., 2007). Finally, in the Senegalese sole, where two splice isoforms were detected, the expression in the brain was higher in pubertal fish than mature fish, and Ss Kiss1r_v1 expression was higher than $\underline{\text { Kiss } 1 r \_v 2}$ in both stages (Mechaly, et al., 2009). This variation in expression pattern between species may be due to species differences or, alternatively, to the presence of different genes or splice variants of the same gene (Mechaly et al., 2009). Nevertheless, this is another aspect of kisspeptin regulation that needs to be clarified.

The Atlantic halibut, Hippoglossus hippoglossus $(\mathrm{Hh})$, belongs to the order Pleuronectiformes and thus presumably has only one $\underline{\text { Kiss } 1 r}$ gene, but whether it has a splice mechanism or not it not known. Atlantic halibut is the largest and longest-lived flatfish, capable of growing to sizes of over $2.2 \mathrm{~m}$ and of living for more than 50 years (Haug, 1990). In addition, Atlantic halibut are slow to mature, requiring 5-7 years. Halibut females generally grow more quickly than males and attain a larger ultimate size (Douglas et al., 2006). Early maturation and reduced growth rates of males are one of the major problems for commercial halibut aquaculture (Norberg et al., 2001). Thus, understanding the control of the initiation of puberty in this species not only has basic interest in knowing about the kisspetinKiss1r system in a flatfish, but may also have potentially significant implications for the halibut aquaculture industry. As a first step in better understanding the onset of puberty in the Atlantic halibut, $\underline{\text { Kiss } 1 r}$ was cloned and its expression analyzed in a variety of tissues at multiple stages of development. 


\section{Experimental Procedures}

\subsection{Fish and sampling}

Juveniles and adults of Atlantic halibut were obtained from Scotian Halibut Ltd. (Woods Harbour, NS). Fish were kept in tanks appropriate for their developmental stage under natural conditions of photoperiod and temperature and were fed twice a day with a commercial diet. These conditions allow Atlantic halibut to mature in captivity. Animals were treated according to the guidelines of the Canadian Council on Animal Care (Demers, 2006) and protocols were approved prior to experimentation by all relevant authorities. Four different year classes (one, three, five and seven year-old) were sampled. Fish were anesthetized with an overdose of MS-222 (Sigma-Aldrich, St. Louis, MO) and sacrificed by decapitation. Tissues were quickly removed under RNase-free conditions, flash frozen in liquid nitrogen and stored at $-80^{\circ} \mathrm{C}$ until used. Gonads (testis and ovaries) were fixed in $4 \%$ paraformaldehyde for further histological examination. Fin clips were taken and stored in 95\% ethanol for DNA extraction. Biometric information including standard length $(\mathrm{cm})$ and weight $(\mathrm{g})$ were obtained for all fishes analyzed.

\subsection{Histological analyses}

After fixation in $4 \%$ paraformaldehyde for approximately $24 \mathrm{hrs}$ at room temperature, gonads were washed for an additional $24 \mathrm{~h}$ in phosphate buffer (PB) $(\mathrm{pH} 7.4)$, dehydrated in an ascending series of ethanol concentrations, cleared in xylene (Fisher Scientific, WA, USA) and embedded in Paraplast (Fisher Scientific, Pittsburgh, PA). Sections (7 $\mu \mathrm{m}$ thick) were cut using a rotary microtome (Microm HM-355), float mounted on Colorfrost/Plus slides (Fisher 
Scientific), warmed on a slide warmer for $1 \mathrm{~h}$ and stained with Instant Haematoxylin and Eosin (H-E) (Sigma). Stained sections were mounted in Permount (Fisher Scientific) under coverslips, examined on a DMRE Leica light microscope and photographed using Compix imaging software. Stages of gametogenesis were determined according to the different germ cell types present as previously described (Hendry et al., 2002).

\subsection{Partial cloning of Atlantic halibut Kiss Ir gene}

Total RNA was isolated from frozen tissue with TRIZOL Reagent (Invitrogen), its quality checked in a $1.5 \%$ agarose gel stained with SYBR safe (Syber Safe ${ }^{\mathrm{TM}}$, Invitrogen) and its quantity measured in a NanoDrop® ND-1000 spectrophotometer (NanoDrop® Technologies Inc, Wilmington, DE, USA). All RNAs were treated with DnaseI (Ambion) to avoid genomic contamination of the RNA samples. cDNA synthesis was performed following the manufacturer's instructions using $1 \mu \mathrm{g}$ of RNA with Superscript III Reverse Transcriptase and random hexamer primers (Invitrogen) in a $20 \mu$ reaction volume.

A partial cDNA sequence of Hh $\underline{\text { Kiss } 1 r}$ was first isolated by reverse transcription PCR (RT-PCR) using degenerate oligonucleotides (Hh_Kiss1r-F3 and Hh_Kiss1r-R3) (Table 1) that were designed on the basis of the previously published sequences of Nile tilapia

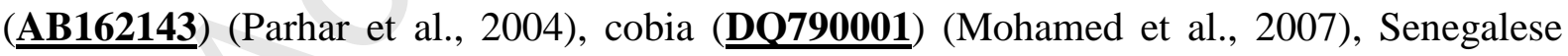
sole (EU136710) (Mechaly et al., 2009), Atlantic croaker (Micropogonias undulates) (DQ347412) and grey mullet ( $\underline{\mathbf{D Q 6 8 3 7 3 7}})$ (Nocillado et al., 2007). PCR reactions were carried out using $1 \mu \mathrm{l}$ of cDNA in a final volume of $25 \mu \mathrm{l}$ containing $2.5 \mu 1$ of 10X PCR reaction buffer $\left(0.75 \mathrm{mM} \mathrm{MgCl}_{2}\right), 0.2 \mathrm{mM}$ of each dATP, dCTP, dGTP, dTTP, 50 pmol of each primer and $0.2 \mu \mathrm{l}$ of rTaq DNA polymerase (G.E. Healthcare). Cycling parameters 
consisted in an initial heat denaturation step at $94^{\circ} \mathrm{C}$ for $5 \mathrm{~min}$ followed by 35 cycles of $30 \mathrm{~s}$ at $94^{\circ} \mathrm{C}, 30 \mathrm{~s}$ at $60^{\circ} \mathrm{C}$ and $30 \mathrm{~s}$ at $72^{\circ} \mathrm{C}$, and finished with a final extension step at $72^{\circ} \mathrm{C}$ for $5 \mathrm{~min}$. Bands of the expected size were purified (Montage PCR, Millipore), ligated into pCR2.1TOPO vector (Invitrogen), using the TOPO TA cloning method and transformed into E. coli competent cells following the manufacturer's instructions. White colonies were selected from X-Gal/IPTG ampicillin agar plates and grown in LB/ampicillin liquid media. Plasmid DNAs were purified with QIAprep Spin Miniprep (QIAGEN) and used as templates in sequencing reaction. The plasmid DNA was purified and sequenced with universal primers using an ABI PRISM 377 automatic sequencer (Applied Biosystems, Foster City, CA, USA). To avoid sequencing errors, ten different plasmids DNAs were sequenced in both directions. The resulting DNA sequences were compared by BLAST analysis to known piscine Kiss1r cDNA sequences available in GenBank.

\subsection{BAC library screening}

An Atlantic halibut BAC library composed of 35,328 clones with an average insert size of $100 \mathrm{~kb}$ was constructed by Lucigen Corp. (Middleton, WI). Based on the partial Hh Kiss1r sequence, primers for an overgo probe (Overgo-Kiss1r-F1 and Overgo-Kiss1r-R1) were designed using Soop (system for optimized overgo picking software; Thomas et al., 2002) for library screening. Overgo probes were labeled according to Ross et al. (1999). Briefly, annealing of the overgo oligo pairs (10 pmol each) was done in $4.5 \mu \mathrm{l}$ of water at $80^{\circ} \mathrm{C}$ for 5 min followed by $37^{\circ} \mathrm{C}$ for $10 \mathrm{~min}$ and then stored on ice. Labeling was carried out by adding $2.0 \mu \mathrm{l} 5 \mathrm{X} \mathrm{OLB}-\{\mathrm{A}, \mathrm{C}\}, 0.5 \mu \mathrm{l}$ of $2 \mathrm{mg} / \mathrm{ml}$ acetylated BSA (New England Biolabs, Ipswich, MA), $0.5 \mu 1$ each of $\left[\alpha^{-32} \mathrm{P}\right] \mathrm{dATP}$ and $\left[\alpha^{-}{ }^{32} \mathrm{P}\right] \mathrm{dCTP}(10 \mu \mathrm{Ci} / \mu \mathrm{l}, \sim 3000 \mathrm{Ci} / \mathrm{mmol}$, Perkin Elmer, Shelton, Connecticut) and $1 \mu \mathrm{l}(2 \mathrm{U} / \mu \mathrm{l})$ of Klenow enzyme (New England 
Biolabs, Ipswich, MA). For ease of image alignment, an overgo probe from E. coli was also labeled. The reactions were incubated at room temperature for $1 \mathrm{~h}$. Fifteen minutes before the end of the incubation $1 \mu \mathrm{l}$ of a cold chase $(200 \mu \mathrm{M}$ each of dATP and dCTP) was added. Unincorporated dNTP's were removed using NICK Sephadex G50 columns (GE Healthcare Baie d'Urfe, Quebec). Filters were pre-hybridized in roller bottles in a hybridization oven using Church's hybridization buffer (Ross et al., 1999) containing $0.5 \mathrm{ml}$ sonicated salmon sperm DNA (10 mg/ml) (Ambion, Austin, Texas) that had been heated to $100^{\circ} \mathrm{C}$ for $5 \mathrm{~min}$ immediately before use. Pre-hybridization was carried out for $3 \mathrm{~h}$ at $55^{\circ} \mathrm{C}$. The prehybridization solution was then replaced with $25 \mathrm{ml}$ of fresh Church's buffer containing salmon sperm DNA to which was added the labeled denatured $\left(95^{\circ} \mathrm{C}\right.$ for $\left.10 \mathrm{~min}\right) \underline{\mathrm{Kiss} 1 \mathrm{r}}$ and E. coli (2\% of the $\underline{\text { Kiss } 1 r}$ volume) overgo probes. Hybridization was carried out for $72 \mathrm{~h}$ at $55^{\circ} \mathrm{C}$. Following hybridization the filters were rinsed once with $4 \mathrm{X}$ SSC containing $0.1 \%$ SDS at room temperature and then extensively washed at $55^{\circ} \mathrm{C}$ for $30 \mathrm{~min}$ : $2 \mathrm{X} 1$ liter each of $2 \mathrm{X}$ $\mathrm{SSC} / 0.1 \% \mathrm{SDS}, 1 \mathrm{X} \mathrm{SSC} / 0.1 \% \mathrm{SDS}$ and $0.5 \mathrm{X}$ SSC/0.1\% SDS. The filters were then exposed to Bio MS film (Kodak) with Biomax MS intensifying screens (Kodak) at $-80^{\circ} \mathrm{C}$ for $24-48 \mathrm{~h}$.

\subsection{Genomic structure of Hh Kiss Ir gene}

Positive clones were isolated, tested by PCR and purified using a Qiagen Large Construct Kit (Qiagen). The BAC DNAs were sequenced on a Roche GS-FLX by the McGill University and Genome Quebec Innovation Centre. The contigs returned from the GS-FLX sequencing had a gap in intron I of the Hh $\underline{\text { Kisslr }}$ gene. To obtain the complete gene sequence, genomic DNA was amplified with primers located in intron I (Intron I-F1 and Intron I-R1) (Table 1). PCR reactions were carried out in a final volume of $25 \mu 1$ containing $2.5 \mu \mathrm{l}$ of 10x PCR reaction buffer with $0.75 \mathrm{mM}$ of $\mathrm{MgCl}_{2}, 0.2 \mathrm{mM}$ of each dATP, dCTP, 
dGTP, dTTP, 50 pmol of each primer and $0.2 \mu 1$ of rTaq DNA polymerase (G.E. Healthcare). PCR was carried out with an initial heat denaturation at $94^{\circ} \mathrm{C}$ for $5 \mathrm{~min}$, followed by 35 cycles of $30 \mathrm{~s}$ at $92^{\circ} \mathrm{C}, 30 \mathrm{~s}$ at $55^{\circ} \mathrm{C}$ and $30 \mathrm{~s}$ at $72^{\circ} \mathrm{C}$, and finished with the final extension step at $72^{\circ} \mathrm{C}$ for 5 min. PCR products were analyzed on $1.5 \%$ agarose gels and bands of the expected size were excised and purified by gel extraction (Qiaquick-Qiagen). The PCR products were directly sequenced by Genewiz Inc. (South Plainfield, NJ). Partial sequences were assembled and edited using Bioedit software version 7.0.5.3 (Hall, 1999).

\subsection{DNA sequence and phylogenetic analysis}

The location of the putative signal peptide cleavage site of halibut Kiss1r was predicted using the SignalP server of the Center for Biological Sequence Analysis (http://www.cbs.dtu.dk/services/SignalP/). The seven TMDs helices were predicted by the HMMTOP Server (Tusnády and Simon, 2001). Upstream sequences of fish Kiss 1r-2 were analyzed with Meme (Bailey and Elkan, 1994) and conserved regions were compared to the Transfac database (Wingender et al., 1996) with Tomtom (Gupta et al., 2007). Multiple alignments and phylogenetic analysis was performed using the amino acid sequences of the seven TMDs of Kiss1r available from GenBank and Ensembl. The sequence sources and GenBank accession numbers were as follow: dog ( $\underline{\text { Canis lupus familiaris }}$ ) ( $\underline{\mathbf{X M} \text { 850105}}$ ), sheep $(\underline{\text { Ovis aries }})(\underline{\mathbf{A B Y} \text { 61032 }})$, rhesus macaque $(\underline{\mathbf{X P} \mathbf{0 0 1 1 1 7 1 9 8}})$, mouse ( $\underline{\mathbf{N P} 444474})$, rat

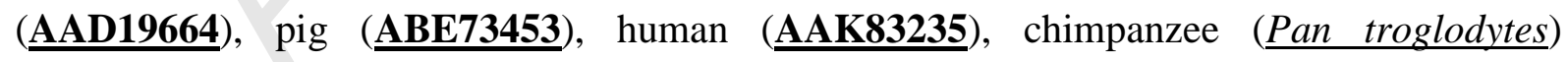

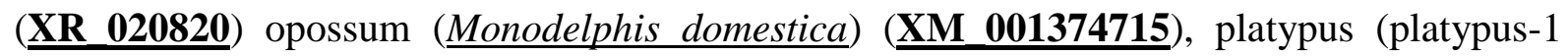
Ultra 266:390150;395924; platypus-1B, Contig 15629:1100:6789), clawed frog (clawed frog-1A, EU85678; clawed frog-1B $\underline{\mathbf{E U 8 5 3 6 7 9}}$; clawed frog-2, $\underline{\mathbf{E U 8 5 3 6 8 0}}$ ), medaka (medaka-1, $\quad \underline{\text { Chromosome 9:4480521:4500733; }}$ medaka-2, 
17:29839761:29855706); zebrafish (zebrafish-A, $\underline{\text { ABV44612 }}$; zebrafish-B, ABV44613); goldfish (goldfish-A, $\underline{\text { ACK77792; }}$ goldfish-B, $\underline{\text { ACK77793)}}$; bullfrog (吕D44939), fathead

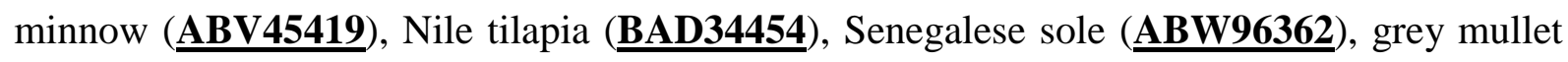
(ABG76790), cobia ( $\underline{\mathbf{A B G 8 2 1 6 5}})$, Atlantic croaker $(\underline{\mathbf{A B C 7 5 1 0 1}})$ and Atlantic halibut (GQ330487). Additionally, sequences for several species were retrieved from genome sequences (http://www.ensembl.org): three-spined stickleback, pufferfish, fugu, lesser hedgehog (Mechaly et al., 2009) and Anole lizard (․ㅡolis carolinensis), pika ( $\underline{\text { Ochotona }}$

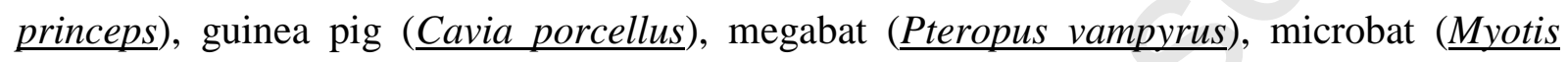

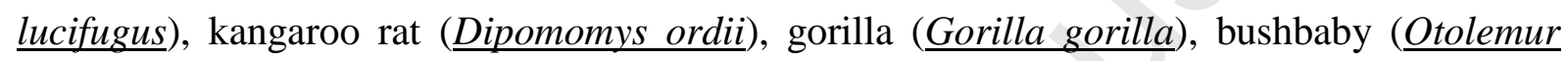
garnettii), dolphin ( $\underline{\text { Tursiops truncates }}$ ), orangutan ( $\underline{\text { Pongo pygmaeus }}$ ) and mouse lemur (Microcebus murinus). Sequences were aligned using Clustal W (Thompson et al., 1994) and edited in Bioedit (Hall, 1999). Sequence alignment was based on the TMDs because adjacent regions were difficult to align and therefore to assign homology among the amino acid residues. A phylogenetic tree was constructed using the neighbor-joining method (Saitou et al., 1987) using amino acid Poisson distance. Evaluation of statistical confidence in nodes was based on 500 nonparametric bootstrap replicates (Felsenstein et al., 1985). All phylogenetic analysis were conducted on MEGA version 4 (Tamura et al., 2007)

\subsection{Tissue-specific expression of Hh $\underline{\text { Kiss } 1 r}$}

Total RNA isolation and cDNA synthesis from brain, ovary, testis, liver, muscle, stomach, heart, intestine and kidney, from three and seven year old males and females were carried out following the protocol described in section 2.3. The resulting cDNAs were used to amplify Hh $\underline{\text { Kiss } 1 r}$ by RT-PCR using the RT Hh Kiss1r-F2 and -R2 primers (Table 1). The PCR cycling conditions for Hh $\underline{\text { Kiss } 1 r}$ were: 5 min at $94^{\circ} \mathrm{C} ; 35$ cycles of $30 \mathrm{~s}$ at $94^{\circ} \mathrm{C}, 30 \mathrm{~s}$ at 
$55^{\circ} \mathrm{C}, 30 \mathrm{~s}$ at $72^{\circ} \mathrm{C}$ and a final extension of $5 \mathrm{~min}$ at $72^{\circ} \mathrm{C}$. Amplification of $\beta$-actin RNA was done as a control using the RT Hh $\beta$ actin-F1 and -R1 primers (Table 1) under the same conditions. A no-template control (NTC) was included to ensure that contamination of reagents had not occurred. PCR products were resolved on a $1 \%$ agarose gel stained with ethidium bromide.

\subsection{Microsatellite analysis}

For immature fish with undeveloped gonads, sex was determined by genotyping with five microsatellite markers (Hhi4IMB, Hhi39IMB, Hhi52IMB, Hhi62IMB, Hhi68IMB; Reid et al., 2007) to establish their pedigree and sex was subsequently inferred from the inheritance of paternal alleles (D. Reid, M. Reith, unpublished). In this case, genomic DNA was extracted from fin clips $(8-10 \mathrm{mg})$ using the Puregene DNA purification/extraction kit (Gentra Systems, USA) as per the solid-tissue extraction method. The standard PCR cocktail included: $10 \mathrm{X}$ high fidelity buffer $(20 \mathrm{mM}$ Tris- $\mathrm{HCl}, 50 \mathrm{mM} \mathrm{KCl}, 1.5 \mathrm{mM} \mathrm{MgCl}$ ) (Larova GmbH, Germany), $200 \mu \mathrm{M}$ of each dNTP; 0.4 to 0.8 pmol each of forward and reverse primer, 0.25 units of high fidelity Taq DNA polymerase (Larova GmbH, Germany) and 0.05 $\mu 1$ of BSA. The PCR reactions contained $9.5 \mu \mathrm{l}(8.4 \mu \mathrm{l}$ PCR cocktail and $1.1 \mu \mathrm{l}$ of $50 \mathrm{ng} / \mu \mathrm{l}$ DNA) reactions in a 96 well polypropylene microplate and were run on a Techne TC-412 (Techne, USA). PCR conditions were an initial denaturing of $95^{\circ} \mathrm{C}$ for $5 \mathrm{~min}$, followed by 35 cycles of $95^{\circ} \mathrm{C}$ for $30 \mathrm{~s}, 56^{\circ} \mathrm{C}$ (for markers 3 and 5) or $58^{\circ} \mathrm{C}$ (for markers 1,2 and 4) for $30 \mathrm{~s}$ and $72^{\circ} \mathrm{C}$ for $45 \mathrm{~s}$ and finally $5 \mathrm{~min}$. at $72^{\circ} \mathrm{C}$. Markers 1,2 and 4 were run in a single reaction and markers 3 and 5 were run in a second reaction. For each sample, $1.5 \mu$ lof the first PCR and $2.5 \mu \mathrm{l}$ of the second PCR were combined with $35 \mu$ l CEQ sample loading solution and $0.5 \mu \mathrm{l}$ of internal DNA size standard (CEQ) into a CEQ sample plate. Pedigree analysis was 
performed

using

PROBMAX

software

(Danzmann

1997)

(http://www.uoguelph.ca/ rdanzman/software/PROBMAX/) using previously collected genotypes from potential parents.

2.9. Determination of Hh $\underline{\text { Kiss } 1 r}$ mRNA levels in brain and gonads

The expression pattern of Hh $\underline{\text { Kiss } 1 r}$ was analyzed in whole brain and ovaries and testis from four different year-classes (1, 3, 5 and 7 years old) by real-time quantitative PCR (qPCR). RNA was isolated as indicated above and it was further purified with a RNA cleanup column (Qiaprep, Qiagen) and a second DNAse treatment, in which $20 \mu \mathrm{g}$ of purified RNA were treated with $2 \mu 1$ of DnaseI (Ambion) and $1 \mu l$ of DnaseI Reaction Buffer in a final volume of $25 \mu 1$. Aliquots of the RNA were analyzed with the Agilent 2100 Bioanalyzer (Agilent Technologies) to check the quality of the samples. The Hh $\underline{\text { Kiss } 1 r}$ primers used for qPCR were located in exons 3 and 4 and designed to span intron III (RT Hh Kiss 1r-F2 and RT Hh Kiss1r-R2) (Table 1).

The qPCR amplification reaction mixture contained $2 \mu$ of diluted cDNA (1:3) (freshly synthesized from $1 \mu \mathrm{g}$ of RNA), $4 \mu \mathrm{M}$ of each primer, and $10 \mu \mathrm{l}$ of SYBR Green PCR Master Mix (Roche) in a final volume of $20 \mu$ l. Thermal cycling conditions comprised heating to $95^{\circ} \mathrm{C}$ for $10 \mathrm{~min}$ to activate the FastStart Taq DNA Polymerase (Qbiogene, Inc), 40 cycles at $95^{\circ} \mathrm{C}$ for $10 \mathrm{~s}$ and $60^{\circ} \mathrm{C}$ for $30 \mathrm{~s}$. At the end of the PCR cycles, the qPCR products were immediately analyzed using a dissociation curve step to confirm that only a single PCR product was amplified. No-template control reactions for every primer pair were also included on each reaction plate to check for external DNA contamination. The amplification efficiency (E) of each primer set/gene target was determined in validation assays containing serially diluted cDNA templates (1:3, 1:10, 1:30, 1:100, 1:300 and 1:1000). Efficiency was estimated 
as $\mathrm{E}=10(-1 /$ slope $)$. The amplification efficiencies were 1.959 and 1.989 for the Hh $\underline{\text { Kiss } 1 r}$ and $\beta$-actin, respectively. The slopes of the curve were -3.424 and -3.349 and the melting temperatures $\left(\mathrm{T}_{\mathrm{M}}\right)$ were 86.4 and 82 , respectively. A single peak was obtained from each gene during melt curve analysis, demonstrating specificity of the primers. PCR products were resolved on $1 \%$ agarose gel stained with ethidium bromide to verify the expected size of the band.

Data were analyzed using the comparative Ct method (Bustin, 2000) (also known as the DDCt method) to calculate relative changes in gene expression using the Light Cycler 480 Software (release 1.5.0, Roche). Fold change (or relative quantification, RQ) was calculated from the DDCt. The LightCycler Relative Quantification Software (Roche) was used for determining calibrator-normalized target/reference ratios with automated efficiency-corrected quantification according to the recommendations of the manufacturer. Fold change was normalized to the endogenous reference gene $\underline{\beta \text {-actin }}$. Determinations were carried out in technical triplicates for the Hh $\underline{\text { Kiss } 1 r}$ and $\underline{\beta \text {-actin }}$ genes. The RQ values for each sample were averaged and the standard error was calculated, yielding the average fold change of the target gene.

\subsection{Statistical analyses}

The results are presented as mean \pm standard error of the mean (S.E.M). Statistical analyses were performed using the SPSS v16 Software. The significance of pairwise comparisons of the mRNA levels of Hh $\underline{\text { Kiss } 1 r}$ in brain of males and females was determined

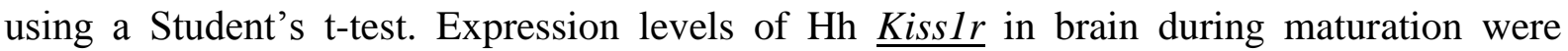
analyzed by a one-way ANOVA. Differences were accepted as significant when $\mathrm{P}<0.05$. 


\section{Results}

3.1. Cloning and sequencing of the full-length Hh $\underline{\text { Kiss } 1 r-2}$ gene

Using degenerate primers located within exon 5, a 202 bp fragment of Hh $\underline{\text { Kiss } 1 r-2}$ was obtained by PCR. The full-length Hh $\underline{\text { Kiss } 1 r \text { - } 2}$ gene was obtained by screening a BAC library with an overgo probe based on the initial Hh $\underline{\text { Kiss } 1 r-2}$ partial sequence. Two positive clones, both containing the complete Hh $\underline{\text { Kiss } 1 r-2}$, were isolated, purified and sequenced. Sequence assembly resulted in a small number (6-12) of contigs for each BAC clone, with Hh $\underline{\text { Kiss } 1 r-2}$ split between two contigs in both cases. One contig contained upstream sequences, exon I and the beginning of intron I, while the second contig contained the end of intron I, the remaining coding region and downstream sequences. PCR reactions using primers flanking the gap between the Kiss1r-2 contigs (Intron I-F1 and R1) were used to complete the sequence of intron I. The complete Hh $\underline{\text { Kiss } 1 r-2}$ sequence was assembled and deposited in GenBank (accession number GQ330487).

\subsection{Characterization of the Hh $\underline{\text { Kiss } 1 r-2}$}

The coding region of the Hh $\underline{\text { Kiss } 1 r-2}$ spans 9,338 bp, which includes 1,146 bp for the five exons of the open reading frame and 8,192 bp for the four introns $(2,425,5,308,94$ and $365 \mathrm{bp}$ for introns I, II, III and IV, respectively). A putative poly-A signal, AAAAAAACAAAAA, was found in the presumptive 3' UTR. Alignment of the Hh $\underline{\text { Kiss } 1 r-2}$ sequence with those of other teleost fish demonstrated a high degree of nucleotide identity (> $86 \%)$. The sizes of the five exons of the $\underline{\text { Kiss } 1 r-2}$ gene from the two pleuronectiformes fishes, Atlantic halibut and Senegalese sole were very similar in length, whereas the sizes of the introns varied (Table 2). Translation of the complete Hh $\underline{\text { Kiss } 1 r-2}$ coding region predicts a 
381 amino acid protein that has a high degree of sequence similarity to Kiss1r proteins from other fish. As in other Kiss1r, seven transmembrane domains were detected (Figure 1 and Figure 2), as well as a 47 amino acid signal peptide (Figure 2).

\subsection{Synteny analysis of Hh $\underline{\text { Kiss } 1 r-2}$}

The larger of the two BAC clones encoding Hh Kiss1r-2 contained sequences encoding several flanking genes, including a partial $\underline{a t p 6 v 0 b}$ (encoding V-type proton ATPase $21 \mathrm{kDa}$ proteolipid subunit), three microRNA genes ( $\underline{m i R-23 a}, \underline{m i R-27 a}$ and $\underline{m i R-24}), \underline{r a b L 5}$ (encoding rab-like protein 5) and a partial $\underline{o d f 2 L}$ (encoding sperm tail outer dense fiber protein 2-like). The organization of genes around the Hh $\underline{\text { Kiss } 1 r-2}$ locus was compared to that of other fish $\underline{\text { Kiss } 1 r \text {-2 }}$ with available genome sequences (Figure 3). Interestingly, the $\underline{a t p 6 v 0 b} \sim \underline{K i s s 1 r-2} \sim \underline{m i R-23 a} \sim \underline{m i R-27 a} \sim \underline{m i R-24}$ gene organization is conserved in all six species, with $\underline{\mathrm{b} 4 \mathrm{galt} 2}$ located upstream of $\underline{\mathrm{atp} 6 v 0 \mathrm{~b}}$ in the species with full genome sequences. Downstream of the microRNA genes, $\underline{\operatorname{rabL5}} \sim \underline{\operatorname{odf} 2 L}$ is conserved in medaka, three-spined stickleback and Atlantic halibut, while $\underline{\operatorname{atp} 5 L}$ is present in both pufferfish and fugu. The conservation of flanking genes among fish $\underline{\text { Kiss } 1 r-2}$ clearly supports a common ancestry, with subsequent taxa-specific rearrangements downstream of micro RNA genes.

\subsection{Phylogenetic analysis of Kiss 1r}

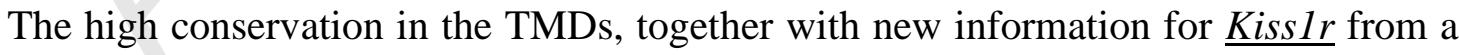
large number of species, facilitated the alignment of 42 Kiss $1 \mathrm{r}$ amino acid sequences. Of the 36 species analyzed, five of them contained more than one paralogous gene, with the clawed frog being the only species with three genes and medaka, zebrafish, goldfish and platypus with two genes. The phylogenetic analysis (Figure 4A) clustered all Kiss1r sequences from 
placental mammals in a single group. Monotreme (platypus) and marsupial (opossum) mammalian Kiss1r-1 sequences are represented by branches at the base of this cluster. Similarly, a strongly supported (97\%) cluster groups all fish Kiss1r sequences along with those from some reptiles and amphibia. Following the scheme of Lee et al. (2009), the cluster containing all mammalian plus the clawed frog-1A sequences is designated Kiss1r-1, while the cluster containing all piscine sequences plus sequences from lizard and some amphibia is designated Kiss1r-2. In turn, the Kiss1r-2 cluster could be subdivided into two. One, named Kiss1r-2A contained all piscine species that have only one Kiss1r gene plus two species of amphibia, and the other, named Kiss1r-2B, containing one reptile (anole lizard), amphibian (clawed frog) and those fish with a second Kiss1r gene (which were originally named medaka-1, goldfish-B, zebrafish-B). Kiss1r-2B sequences were intermediate between the Kiss1r-2A sequences and mammalian sequences (Kiss1r-1).

\subsection{Analysis of the putative Hh $\underline{\text { Kiss } 1 r-2}$ promoter region}

The 980 bp upstream sequence from Hh $\underline{\text { Kiss } 1 r-2}$ along with 1500 bp of sequence upstream of the ATG start from the zebrafish, medaka, three-spined stickleback, fugu and pufferfish $\underline{\text { Kiss } 1 r-2}$ were analyzed for conserved sequence regions using Meme (Bailey and Elkan, 1994). Six conserved regions were identified on the coding strand that ranged in size from 11 to 29 bp (Figure 5). All conserved regions fall within an $\sim 1100$ bp region upstream of the $\underline{\text { Kiss } 1 r-2}$ ATG. Two of these regions showed considerable similarity to the binding sites for the transcription factors MIF-1 (black boxes in Figure 5) and estrogen receptor (grey boxes). Notable are the conserved location of the estrogen receptor-like sequences near -100 in five of six species and the conserved, adjacent arrangement of the regions represented by the black and white boxes in four of the species. 


\subsection{Determination of the sex and development stages of Atlantic halibut}

Sex was determined and fish were classified to their stage of maturation based on the different types of germinal cells present in gonads (Weltzien et al., 2002; Hendry et al., 2002). Sex in several immature fish with undeveloped gonads was determined by pedigree analysis and the inheritance of a sex-specific microsatellite marker (D. Reid, M. Reith, unpublished). The histological analysis (Figure 6) confirmed that all fish from the one-year class were immature, with spermatogonia present in the males and primordial oocytes in females. The three-year-old fish were entering the early stages of puberty, as determined by the presence of spermatocytes and previtellogenic oocytes. The five-year-old fish were in middle of sexual development, showing spermatids in males, and vitellogenic oocytes in females. Finally, the seven-year class fish were sexually mature with late spermatogenesis evident in males and late vitellogenesis in females.

\subsection{Tissue distribution of Hh $\underline{\text { Kiss } 1 r-2}$ in early puberty and adult fish}

The expression of Hh $\underline{\text { Kiss } 1 r-2}$ was analyzed by RT-PCR in different tissues from fish from two year-classes (three- and seven-year-old fish), which corresponded to two different maturation stages, early puberty and mature, respectively. Hh $\underline{\text { Kiss } 1 r-2}$ was most highly expressed in the brain in all four combinations of sex and year class (Figure 7). In the threeyear-old fish, Hh $\underline{\text { Kiss } 1 r-2}$ expression was detectable in most tissues at low levels, with intestine and stomach showing intermediate expression levels in the male and stomach and kidney having intermediate levels in the female. In the seven-year-old fish, Hh $\underline{\text { Kiss } 1 r-2}$ expression could only be detected in the brain and stomach in both sexes. 
3.8. Expression of Hh $\underline{\text { Kiss } 1 r-2}$ in brain and gonads during development

Real time PCR (qPCR) was used to quantify the expression of Hh $\underline{\text { Kiss } 1 r-2}$ in brain and gonads from the different year classes. For all four year-classes, $\underline{\text { Hh Kiss } 1 r-2}$ expression in the brain was not significantly different between the two sexes $(P=0.981, P=0.719, P=$ 0.170 , and $P=0.555$ ), and thus values were pooled together. One-way ANOVA showed a significant increase in the expression of Hh $\underline{\text { Kiss } 1 r-2}$ in the brain (Figure 8A) coinciding with the onset of puberty (three-year-old class) in comparison with the rest of the year-classes $(P<$ 0.05). On the other hand, in gonads (Figure 8B), Hh $\underline{\text { Kiss } 1 r-2}$ expression was only detected in individuals at an extremely low level compared to the brain (>100-fold lower expression) and only in fish from the one-year-old class. In this class, no differences were detected between sexes $(P=0.945)$. No expression was detected in the rest of the year classes.

\section{Discussion}

Kiss1r is a G-protein-coupled receptor highly expressed in the brain (Kuohung and Kaiser 2007) and found to be associated with GnRH neurons in different animals, including rat, mice and Nile tilapia (Irwing et al., 2004; Messager et al., 2005; Parhar et al., 2004). Kiss1r has been linked to the regulation of the initiation of puberty in vertebrates (Smith et al., 2006; Tena-Sempere et al., 2006), although it may have additional physiological functions (Makri et al., 2008; Roa et al., 2008).

The analysis of the genomic structure of the Hh $\underline{\text { Kiss } 1 r-2}$ gene revealed the presence of five exons and four introns, a gene organization that is conserved from teleost fish to amphibians and mammals (van Aerle et al., 2008). Comparison of the coding sequence with 
other fish revealed a high degree (>90\%) of homology. Comparison to the gene organization in a closely related species, the Senegalese sole (Mechaly et al., 2009), revealed substantial length differences in introns II and IV. Interestingly, intron III of Atlantic halibut and Senegalese sole exhibited a considerable degree of sequence conservation (50\% identity) and a similar length, 94 and 81 bp, respectively. In Senegalese sole, intron III missplicing results in a second isoform with a different expression pattern than the full-length form. Similar to the Senegalese sole, the Hh Kiss1r-2 intron III has a branch point with low sequence conservation compared to the consensus sequence. Despite numerous attempts, alternative $\underline{\text { Kiss } 1 r}$ isoforms could not be detected in a variety of Atlantic halibut tissues. However, since not all tissue-developmental stages combinations could be tested, alternative splicing of $\mathrm{Hh}$ $\underline{\text { Kiss } 1 r-2}$ remains a possibility. Alternative splicing of $\underline{\text { Kiss } 1 r}$ has also been detected at intron I in sheep (Genbank accessions $\underline{\text { EU272411 }}$ and $\underline{\text { EU272412) }}$ and with the deletion of the entire TMD5 in mouse ( $\underline{\mathbf{E U 5 3 2 4 3 6}}$ and $\underline{\text { EU532437)}})$, both of which result in proteins with altered TMDs. Alternative splicing may provide an additional mechanism for regulating the expression of Kiss 1r or for directing it to an alternative subcellular location.

An exhaustive phylogenetic analysis of Kiss1r provided insights into its evolutionary history. The phylogenetic relationships described here (Figure 4) are in general in agreement with the evolutionary tree constructed in our previous study (Mechaly et al., 2009), although a close inspection of the newer tree, which contains more species (36 vs 20 in Mechaly et al., 2009) reveals some unexpected relationships and suggests that gene duplications have occurred in this lineage. Placental mammalian Kiss1r sequences cluster tightly together (Kiss1r-1 cluster) with the marsupial and monotreme sequences branching from the base of this cluster. The observation that the platypus-1 and clawed frog-1A sequences share a well- 
supported common branch suggests that the clawed frog-1A Kiss 1r shares a common ancestor with the mammalian Kiss1r. Most of the fish sequences cluster in a tight group at the end of the tree while the medaka-1, zebrafish-B and goldfish-B are located on a separate branch. Reptile and amphibian sequences cluster between these branches and distance analysis suggests that the clawed frog-2 and bullfrog sequences are most closely related to the main fish group (Kiss1r-2A group), while the clawed frog-1B and anole lizard sequences group with the three outlying medaka-1, zebrafish-B and goldfish-B sequences (Kiss1r-2B group). Thus, Kiss1r-2B do not cluster with the Kiss1r-1 of mammals, as surmised earlier (Biran et al., 2008; Li et al., 2009), but are an additional, non-mammalian form of Kiss1r. Our interpretation of $\underline{\text { Kiss Ir }}$ evolution (Figure 4B) is that an ancestral gene duplication occurred prior to the emergence of fish, leading to the $2 \mathrm{~A}$ and $2 \mathrm{~B}$ groups, and that an additional duplication of the $2 \mathrm{~B}$ gene, prior to the emergence of amphibians, resulted in the ancestor of clawed frog-1A. This latter gene appears to be the only $\underline{\text { Kiss } 1 r}$ version retained in higher vertebrates, assuming it is present in reptiles. A duplication of Kiss 1 r-1 appears to have occurred within the monotremes. Thus, the evolutionary relationships within the fish Kiss1r2A group and within the placental mammalian Kiss1r-1 group does not reflect the expected organismal evolutionary relationships but rather the evolution of this gene lineage. In this regard, it would be interesting to know the structure and sequence of the Kiss $1 r-1$ gene(s) in other vertebrates, including Sarcopterygian fishes. Also, as of today, the are still no avian $\underline{\text { Kiss } 1 r}$ sequences that can be identified in public databases, despite several attempts.

Among fish, many species appear to have lost $\underline{\text { Kiss } 1 r-2 B}$. Genome sequences from fugu, pufferfish and three-spined stickleback demonstrate the presence of only the $2 \mathrm{~A}$ form of $\underline{\text { Kiss } 1 r-2}$. Extensive searches with multiple degenerate primers have failed to detect a second 


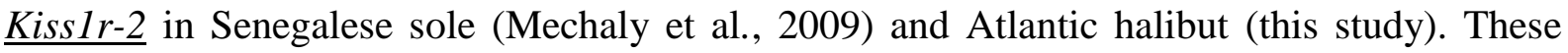
results suggest that $\underline{\text { Kiss } 1 r-2 B}$ could be lost in some of the most derived teleost orders, including the Pleuronectiformes and Tetraodontiformes, as well as some other Acanthopterygian fish. It is not yet clear whether the loss of $\underline{\text { Kiss } 1 r-2 B}$ was a single event in the evolution of fish or has independently occurred multiple times.

Recent studies have shown that Kiss 1 also underwent a duplication in some fishes (Felip et al., 2009), a situation similar to the one described for the Kiss $1 r$ gene, whereas in mammals, with the exception of the platypus, only one $\underline{\text { Kiss } 1}$ gene is observed. Interestingly, the three teleost species in which two $\underline{\text { Kiss } 1}$ genes have been reported so far, i.e., zebrafish (Kitahashi et al., 2008), medaka (Kanda et al., 2009) and goldfish (Yang et al., 2009), also have two Kiss1r genes. To the best of our knowledge, there are no species with only one Kiss1 gene and two Kiss1r genes or vice versa.

This study also provides the first synteny analysis of the Kiss 1 r-2 region. Results

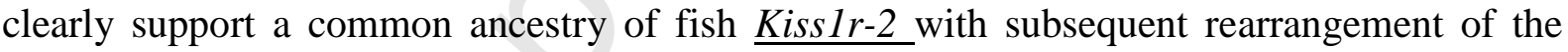
genes downstream of the three miRNA genes showing taxa-specific organization. The highly conserved nature of the $\underline{\text { Kiss } 1 r \text { - } 2}$ region suggests that the flanking regulatory sequences are also likely to be conserved. As a first attempt at defining potential transcription factor binding sites, bioinformatic analysis has identified six conserved regions in fish $\underline{\text { Kiss } 1 r-2}$ upstream sequences, two of which show some similarity to known transcription factor binding sites. We are hesitant to suggest that these transcription factors bind to these sites and regulate $\underline{\text { Kiss } 1 r-2}$ without further experimental analysis. However, they provide potential targets for future indepth investigation of $\underline{\text { Kiss } 1 r \text {-2 }}$ regulation in different species. 
Analysis by qPCR of $\underline{\text { Kiss } 1 r}$ expression in different developmental stages revealed no major differences in expression between male and female Atlantic halibut. A similar absence

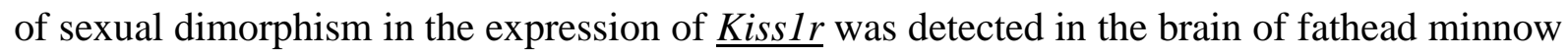
(Filby et al., 2008). The Hh $\underline{\text { Kiss } 1 r-2}$ expression level in the brain was significantly higher in early puberty stages than the other stages investigated. A similar pattern of expression throughout development was observed in some teleost fish such as the fathead minnow (Filby et al., 2008) and for the zebrafish-A gene (Biran et al., 2008). However, in other species such as Nile tilapia and cobia, $\underline{\text { Kiss } 1 r}$ expression continues to increase as puberty advances (Parhar et al., 2004; Mohamed et al., 2006).

The expression of Hh $\underline{\text { Kiss } 1 \text {-2 } 2}$ in gonads of 1-year-old halibut was 400-fold lower than brain, which is in the same order of magnitude as the 100 -fold difference observed in Nile tilapia (Martínez-Chávez et al., 2008), but higher than the 14-fold difference observed in fathead minnow (Filby et al., 2008) or the 10-fold difference observed in mature female grey mullet (Nocillado et al., 2006). Thus, it seems that regardless of species, the relationship between $\underline{\text { Kiss } 1 r-2}$ expression in the brain and the gonads is in the range of 1-2 orders of magnitude. In the 3, 5 and 7 year classes, $\mathrm{Ct}$ values in gonads were too high to accurately determine Hh $\underline{\text { Kiss } 1 r-2}$ expression levels, while the expression levels in ovaries and testis in the 1 year-old-class were not statistically different. Similar results were observed in studies carried out in rats, where the ovarian expression of $\underline{\text { Kiss } 1 r}$ did not fluctuate during ovulation (Castellano et al., 2006). However, in the Senegalese sole, the Kisslr_v1 isoform showed higher expression in the testis than the ovaries (Mechaly et al., 2009). 
In aquaculture, precocious sexual maturation, usually of males, has significant negative economic impact since early maturing fish are smaller and may have diminished flesh quality. Understanding the hormonal signals of puberty, their detection and the genes they regulate should provide tools to monitor the sexual maturation of fish at a molecular level and eventually develop management practices to avoid triggering this process. The isolation of Hh $\underline{\text { Kiss } 1 r-2}$ and analysis of its gene expression will aid in understanding puberty in this species and provide insights into the evolution and regulation of this developmentally important gene.

In conclusion, in this study we have described the genomic organization of Atlantic

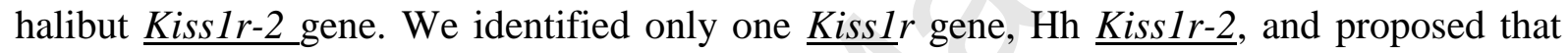
the flatfish, as well as several other orders of fish, have lost the second gene during the evolution of teleost fish. Further, new phylogenetic relationships were proposed based on the analysis of all available Kiss1r sequences. Synteny analysis demonstrates a conserved gene order around the Kiss1r-2 locus in many teleosts and suggests the likelihood of conservation of regulatory regions. Furthermore, the concordant expression patterns of Senegalese sole $\underline{\text { Kiss } 1 r \_v 1}$ and Atlantic halibut $\underline{\text { Kiss } 1 r-2}$, which show higher expression in brain, demonstrates the importance of the kisspeptin-Kiss1r system in the brain, compared to the gonads, during early puberty.

\section{Acknowledgements}

Thanks are due to B. Blanchard and the staff of Scotian Halibut Ltd. for providing fish, D. Reid for help with the fish sampling and for the microsatellite analysis, C. Leggiadro for help with the histology and to Dr. L. C. Knickle for technical advice on qPCR. 


\section{References}

Bailey, T. L., Elkan, C., 1994. Fitting a mixture model by expectation maximization to discover motifs in biopolymers, Proc. Int. Conf. Intell. Syst. Mol. Biol. 2, 28-36.

Biran, J., Ben-Dor, S., Levavi-Sivan, B., 2008. Molecular identification and functional characterization of the kisspeptin/kisspeptin receptor system in lower vertebrates. Biol. Reprod. 79, 776-786.

Bustin, S. A., 2000. Absolute quantification of mRNA using real-time reverse transcription polymerase chain reaction assays. J. Mol. Endocrinol. 25, 169-193.

Castellano, J. M., Gaytan, M., Roa, J., Vigo, E., Navarro, V. M., Bellido, C., Dieguez, C., Aguilar, E., Sánchez-Criado, J. E., Pellicer, A., Pinilla, L., Gaytan, F., Tena-Sempere, M., 2006. Expression of KiSS-1 in rat ovary: putative local regulator of ovulation? Endocrinology 147: 4852- 4862.

Danzmann, R. G., 1997. PROBMAX: A computer program for assigning unknown parentage in pedigree analysis from known genotypic pools of parents and progeny. J. Hered. 88: 333.

Demers, G., Griffin, G., De Vroey, G., Haywood, J. R., Zurlo, J., Bedard, M., 2006. Animal research. Harmonization of animal care and use guidance. Science 312, 700-701.

de Roux, N., Genin, E., Carel, J. C., Matsuda, F., Chaussain, J. L., Milgrom, E., 2003. Hypogonadotropic hypogonadism due to loss of function of the KiSS1-derived peptide receptor GPR54. Proc Natl. Acad. Sci. U.S.A. 100, 10972-10976.

Douglas, B. S., Ross, M. R., 2006. Length at age, sexual maturity and distribution of Atlantic halibut, Hippoglossus hippoglossus L., off the Northeast USA. J. Northw. Atl. Fish. Sci. 36, 81-90.

Felip, A., Zanuy, S., Pineda, R., Pinilla, L., Carrillo, M., Tena-Sempere, M., Gómez, A. 2009. Evidence for two distinct KiSS genes in non-placental vertebrates that encode kisspeptins with different gonadotropin-releasing activities in fish and mammals. Mol. Cell. Endocrinol. 312(1-2): 61-71. 
Felsenstein, J., 1985 Confidence limits on phylogenies - an approach using the bootstrap. Evolution 39, 783-791.

Filby, A. L., van Aerle, R., Duitman, J., Tyler, C. R., 2007. The kisspeptin/gonadotropinreleasing hormone pathway and molecular signaling of puberty in Fish Biol. Reprod. 78, 278-289.

Funes, S., Hedrick, J. A., Vassileva, G., Markowitz, L., Abbondanzo, S., Golovko, A., Yang, S. J., Monsma, F. J., Gustafson, E. L., 2003. The KiSS-1 receptor GPR54 is essential for the development of the murine reproductive system. Biochem. Biophys. Res. Commun. 312, 1357-1363.

Gottsch, M. L., Cunningham, M. J., Smith, J. T., Popa, S. M., Acohido, B. V., Crowley, W. F., Seminara, S., Clifton, D. K., Steiner, R. A., 2004. A role for kisspeptins in the regulation of gonadotropin secretion in the mouse. Endocrinology 145, 4073-4077.

Gupta, S., Stamatoyannopolous, J. A., Bailey, T. Noble, W. S., 2007. Quantifying similarity between motifs. Genome Biol., 8:R24.

Hall T., 1999. BioEdit: a user-friendly biological sequence alignment editor and analysis program for Windows 95/98/NT. Nucleic. Acids. Symp. Ser. 41, 95-98.

Haug, T., 1999. Biology of the Atlantic halibut Hippoglossus hippoglossus (L. 1758). Adv. Mar. Biol. 26, 1-70.

Hendry, C. I., Martin-Robichaud, D. J., Benfey, T. J., 2002. Gonadal sex differentiation in Atlantic halibut. J. Fish. Biol. 60, 1431-1442.

Irwig, M. S., Fraleyb, G. S., Smith, J. T., Acohido, B. V., Popa, S. M., Cunningham, M. J., Gottsch, M. L., Clifton, D. K., Steiner, R. A., 2004. Kisspeptin activation of gonadotropin releasing hormone neurons and regulation of KiSS-1 mRNA in the male rat. Neuroendocrinology 80, 264-272.

Kanda, S., Akazome, Y., Matsunaga, T., Yamamoto, N., Yamada, S., Tsukamura, H., Maeda, K., Oka, Y. 2008. Identification of KiSS-1 product kisspeptin and steroid-sensitive sexually dimorphic kisspeptin neurons in medaka (Oryzias latipes). Endocrinology. 149 (5): 2467-76. 
Kitahashi, T., Ogawa, S., Parhar, I.S. 2009. Cloning and expression of kiss2 in the zebrafish and medaka. Endocrinology 150 (2): 821-31.

Kotani, M., Detheux, M., Vandenbbogaerde, A., Communi, D., Vanderwinden, J. M., Le Poul, E., Brezillon, S., Tyldesley, R., Suarez-Huerta, N., Vandeput, F., Blanpain, C., Schiffmann, S. N., Vassart, G., Parmentier, M., 2001. The metastasis suppressor gene KiSS-1 encodes kisspeptins, the natural ligands of the orphan G protein-coupled receptor GPR54. J. Biol. Chem. 276, 34631-34636.

Kuohung, W., Kaiser, U. A., 2007. GPR54 and KiSS-1: Role in the regulation of puberty and reproduction. Rev. Endocr. Metab. Disord. 75, 355-361.

Lee, D. K., Nguyen, T., O'Neill, G. P., Cheng, R., Liu, Y., Howard, A. D., Coulombe, N., Tan, C. P., Tang-Nguyen, A. T., George, S. R., O'Dowd, B. F., 1999. Discovery of a receptor related to the galanin receptors. Febs. Letters 446, 103-107.

Lee, Y. R., Tsunekawa, K., Moon, M. J., Um, H. N., Hwang, J. I., Osugi, T., Otaki, N., Sunakawa, Y., Kim, K., Vaudry, H., Kwon, H. B., Seong, J. Y., Tsutsui, K., 2009. Molecular evolution of multiple forms of kisspeptins and GPR54 receptors in vertebrates. Endocrinology. 150 (6), 2837-2846.

Li, S., Ren, J., Yang, G., Guo, Y., Huang, L., 2008. Characterization of the porcine Kisspeptins receptor gene and evaluation as candidate for timing of puberty in sows. J. Anim. Breed. Genet.125 (4), 219-227.

Li, S., Zhang, Y., Liu, Y., Huang, X., Huang, W., Lu, D., Zhu, P., Shi, Y., Cheng, C.H., Liu, X., Lin, H., 2009. Structural and functional multiplicity of the kisspeptin/GPR54 system in goldfish (Carassius auratus). J. Endocrinol. 201 (3), 407-18.

Makri, A., Pissimissis, N., Lembessis, P., Polychronakos, C., Koutsilieris M., 2008. The kisspeptin (KiSS1-1)/Gpr54 system in cancer biology. Cancer. Treat. Rev. 34, 682692.

Mechaly, A. S., Viñas, J., Piferrer, F., 2009. Identification of two isoforms of the kisspeptin-1 receptor (kiss1r) generated by alternative splicing in a modern teleost, the Senegalese Sole (Solea senegalensis). Biol. Reprod. 80, 60-69.

Messager, S., Chatzidaki, E. E., Ma, D., Hendrick, A. G., Zahn, D., Dixon, J., Thresher, R. R., Malinge, I., Lomet, D., Carlton, M. B. L., Colledge, W. H., Caraty, A., Aparicio, S. A. 
J. R., 2005. Kisspeptin directly stimulates gonadotropin-releasing hormone release via G protein-coupled receptor 54. Proc Natl. Acad. Sci. U.S.A.102, 1761-1766.

Mohamed, J. S., Benninghoff, A. D., Holt, G. J., Khan, I. A., 2007. Developmental expression of the $\mathrm{G}$ protein-coupled receptor 54 and three GnRH mRNAs in the teleost fish cobia. J. Mol. Endocrinol. 38, 235-244.

Moon, J. S., Lee, Y. R., Oh, D. Y., Hwang, J. I., Lee, J. Y., Kim, J. I., Vaudry, H., Kwon, H. B., Seong, J. Y., 2008. Molecular cloning of the bullfrog kisspeptin receptor GPR54 with high sensitivity to Xenopus kisspeptin. Peptides 30 (1), 171-179.

Muir, A. I., Chamberlain, L., Elshourbagy, N. A., Michalovich, D., Moore, D. J., Calamari, A., Szekeres, P. G., Sarau, H. M., Chambers, J. K., Murdock, P., Steplewski, K., Shabon, U., Miller, J. E., Middleton, S. E., Darker, J. G., Larminie, C. G. C., Wilson, S., Bergsma, D. J., Emson, P., Faull, R., Philpott, K. L., Harrison, D. C., 2001. AXOR12, a novel human $\mathrm{G}$ protein-coupled receptor, activated by the peptide KiSS-1. J. Biol. Chem. 276, 28969-28975.

Nocillado, J. N., Elizur, A., 2008. Neuroendocrine regulation of puberty in fish: insights from the grey mullet (Mugil cephalus) model. Mol. Reprod. Dev. 75, 355-361.

Nocillado, J. N., Levavi-Sivan, B., Carrick, F., Elizur, A., 2007. Temporal expression of Gprotein-coupled receptor 54 (GPR54) gonadotropin-releasing hormones $(\mathrm{GnRH})$, and dopamine receptor D2 (drd2) in pubertal female grey mullet, Mugil cephalus. Gen. Comp. Endocrinol. 150, 278-287.

Norberg, B., Weltzien, F. A., Karlsen, O., Holm, J. C., 2001. Effects of photoperiod on sexual maturation and somatic growth in male Atlantic halibut (Hippoglossus hippoglossus L.). Comp. Biochem. Physiol. B. 129, 357-365.

Oakley, A. E., Clifton, D. K., Steiner, R. A., 2009. Kisspeptin signaling in the brain. Endocrine Rev. doi:10.1210/er.2009-0005.

Ohtaki, T., Shintani, Y., Honda, S., Matsumoto, H., Hori, A., Kanehashi, K., Terao, Y., Kumano, S., Takatsu, Y., Masuda, Y., Ishibashi, Y., Watanabe, T., Asada, M., Yamada, T., Suenaga, M., Kitada, C., Usuki, S., Kurokawa, T., Onda, H., Nishimura, O., Fujino, M., 2001. Metastasis suppressor gene KiSS-1 encodes peptide ligand of a G-protein-coupled receptor. Nature 411, 613-617. 
Ojeda, S. R., Lomniczi, A., Mastronardi, C., Heger, S., Roth, C., Parent, A. S., Matagne, V., Mungenast, A. E., 2006. Minireview: the neuroendocrine regulation of puberty: is the time ripe for a systems biology approach?. Endocrinology 147, 1166-1174.

Parhar, I. S., Ogawa, S., Sakuma, Y., 2004. Laser-captured single digoxigenin-labeled neurons of gonadotropin-releasing hormone types reveal a novel g protein-coupled receptor (Gpr54) during maturation in cichlid fish. Endocrinology 145, 3613-3618.

Reid, D. P., Smith, C. A., Rommens, M., Blanchard, B., Martin-Robichaud D., Reith, M., 2007. A genetic linkage map of Atlantic halibut (Hippoglossus hippoglossus L.). Genetics 177, 1193-1205.

Roa, J., Aguilar, E., Diéguez, C., Pinilla, L., Tena-Sempere, M., 2008. New frontiers in kisspeptin/GPR54 physiology as fundamental gatekeepers of reproductive function. Front. Neuroendocrinol. 29, 48-69.

Ross, R., Ross, X.L., Rueger, B., Laengin, T., Reske-Kunz, A. B., 1999. Nonradioactive detection of differentially expressed genes using complex RNA or DNA hybridization probes. Biotechniques 26 (1), 150-155.

Roseweir, A. K., Millar, R. P., 2009. The role of kisspeptin in the control of gonadotrophin secretion. Hum. Reprod. Update 15, 203-212.

Saitou, N., Nei, M., 1987. The Neighbor-Joining method - a new method for reconstructing phylogenetic trees. Mol. Biol. Evol. 4, 406-425.

Schulz, R. W., Goos, H. J. Th., 1999. Puberty in male fish: concepts and recent developments with special reference to the African catfish (Clarias gariepinus). Aquaculture 177, 512.

Seminara, S. B., Messager, S., Chatzidaki, E. E., Thresher, R. R., Acierno, J. S., Shagoury, J. K., Bo-Abbas, Y., Kuohung, W., Schwinof, K. M., Hendrick, A. G., Zahn, D., Dixon, J., Kaiser, U. B., Slaugenhaupt, S. A., Gusella, J. F., O'Rahilly, S., Carlton, M. B. L., Crowley, W. F., Aparicio, S. A. J. R., Colledge, W. H., 2003. The GPR54 gene as a regulator of puberty. N. Engl. J. Med. 349, 1614-1618.

Shahab, M., Mastronardi, C., Seminara, S. B., Crowley, W. F., Ojeda, S. R., Plant, T. M., 2005. Increased hypothalamic GPR54 signaling: A potential mechanism for initiation of puberty in primates. Proc. Nat. Acad. Sci. 102 6, 2129-2134. 
Smith, J. T., Clifton, D. K., Steiner, R. A., 2006. Regulation of the neuroendocrine reproductive axis by kisspeptin-GPR54 signaling. Reproduction 131, 623-630.

Smith, E. M., Gregory, T. R., 2009. Patterns of genome size diversity in the ray-finned fishes. Hydrobiologia 625, 1-25.

Stafford, L. J., Xia, C. Z, Ma, W. B., Cai, Y., Liu M. Y., 2002. Identification and characterization of mouse metastasis-suppressor KiSS1 and its G-protein-coupled receptor. Cancer Res. 62, 5399-5404.

Tamura, K., Dudley, J., Nei, M., Kumar, S., 2007. MEGA4: Molecular Evolutionary Genetics Analysis (MEGA) Software Version 4.0. Mol. Biol. Evol. 24, 1596-1599.

Taranger, G.L., Carrillo, M., Schulz, R.W., Fontaine, P., Zanuy, S., Felip, A., Weltzien, F.A., Dufour, S., Karlsen, O., Norberg, B., Andersson, E., Hansen, T., 2009. Control of puberty in farmed fish. Gen. Comp. Endocrinol. doi; 10.1016/j.ygcen.2009.05.004

Tena-Sempere, M., 2006. GPR54 and kisspeptin in reproduction. Hum. Reprod. Update 12, 631-639.

Thomas, J. W., Prasad, A. B., Summers, T. J., Lee-Lin, S. Q., Maduro, V. B. V., Idol, J. R., Ryan, J. F., Thomas, P, J., McDowell, J. C., Green, E. D., 2002. Parallel construction of orthologous sequence -ready clone contig maps in multiple species. Genome Res. $12,1277-1285$.

Thompson, J. D., Higgins, D. G., Gibson, T. J., 1994. CLUSTAL W: improving the sensitivity of progressive multiple sequence alignment through sequence weighting, position-specific gap penalties and weight matrix choice. Nucl. Acids Res. 22, 46734680 .

Tusnády, G. E., Simon, I., 2001. The HMMTOP transmembrane topology prediction server. Bioinformatics 17, 849-850.

van Aerle, R., Kille, P., Lange, A., Tyler, C.R., 2008. Evidence for the existence of a functional Kiss1/Kiss1 receptor pathway in fish. Peptides 29, 57-64.

Weltzien, F. A., Andersson, E., Andersen, O., Shalchian-Tabrizi, K., Norberg, B., 2004. The brain-pituitary-gonad axis in male teleosts, with special emphasis on flatfish (Pleuronectiformes). Comp. Biochem. Physiol. A Mol. Integr. Physiol. 137, 447-477. 
Weltzien, F. A., Taranger, G. L., Karlsen, O., Norberg, B., 2002. Spermatogenesis and related plasma androgen levels in Atlantic halibut (Hippoglossus hippoglossus L.). Comp. Biochem. Physiol. A Mol. Integr. Physiol. 132, 567-575.

Wingender, E., Dietze, P., Karas, H., Knuppel, R., 1996. TRANSFAC: A database on transcription factors and their DNA binding sites. Nucl. Acids Res. 24, 238-241.

Yang, B., Jiang, Q., Chan, T., Ko, W. K., Wong, A. O. 2009. Goldfish kisspeptin: Molecular cloning, tissue distribution of transcript expression, and stimulatory effects on prolactin, growth hormone and luteinizing hormone secretion and gene expression via direct actions at the pituitary level. Gen. Comp. Endocrinol. doi; 10.1016/j.ygcen.2009.06.001. 
Table 1. Degenerate and specific primers used in the Hh $\underline{\text { Kiss } 1 r-2}$ cloning, screening, Intron I isolation, qPCR and RT-PCR

\begin{tabular}{llcl}
\hline Primers & Primer sequence $\left(5^{\prime} \rightarrow 3^{\prime}\right)$ & Amplicon & Usage \\
& & size (bp) & \\
\hline Hh_kiss1r-F3 & ATCAAGACDTGGGCCAACTGC & 202 & Partial cloning \\
Hh_Kiss1r-R3 & ATTGTTGCCTTCCTCYGCNGC & & Partial cloning \\
Overgo-Kiss1r-F1 & GAGCCAGCTTCCAAAAGTCCTTCA & 40 & BAC screening \\
Overgo-Kiss1r-R1 & AAGGGGAAGGTTTTCCTGAAGGAC & & BAC screening \\
Intron I-F1 & GCAAATGAATGTGCCAGTGT & $\sim 800$ & Intron I cloning \\
Intron I-R1 & TGCTGTAGGTGCTTTGAGGA & & Intron I cloning \\
RT Hh Kiss1r-F2 & GGTCCAGGCCACTTGTATCA & 116 & qPCR and RT-PCR \\
RT Hh Kiss1r-R2 & TGCTGACGATCATGGCTACT & & qPCR and RT-PCR \\
RT Hh $\beta$ actin-F1 & AAGAAGAAAGAAAAGACGGAGGA & 84 & qPCR and RT-PCR \\
RT Hh $\beta$ actin-R1 & AAGATTTGCCAGAGATGTTTCC & & qPCR and RT-PCR \\
\hline
\end{tabular}

Notes: $\mathrm{Y}=\mathrm{C}$ or $\mathrm{T} ; \mathrm{D}=\mathrm{A}, \mathrm{G}$ or $\mathrm{T} ; \mathrm{N}=\mathrm{A}, \mathrm{C}, \mathrm{G}$ or $\mathrm{T}$ 
Table 2. Intron and exon size in Atlantic halibut $\underline{\text { Kiss } 1 r-2}$ gene (Hh $\underline{\text { Kiss } 1 r-2})$ and Senegalese sole (Ss $\underline{\text { Kiss1r }})$

\begin{tabular}{ccc}
\hline & Hh $\underline{\text { Kiss } 1 \text { - }-2}$ & Ss $\underline{\text { Kiss } 1 r}$ \\
\hline Exon 1 & $261 \mathrm{bp}$ & $252 \mathrm{bp}$ \\
Intron I & $2.5 \mathrm{~kb}$ & $2.5 \mathrm{~kb}$ \\
Exon 2 & $129 \mathrm{bp}$ & $129 \mathrm{bp}$ \\
Intron II & $5.3 \mathrm{~kb}$ & $0.2 \mathrm{~kb}$ \\
Exon 3 & $136 \mathrm{bp}$ & $131 \mathrm{bp}$ \\
Intron III & $0.9 \mathrm{~kb}$ & $0.8 \mathrm{~kb}$ \\
Exon 4 & $239 \mathrm{bp}$ & $244 \mathrm{bp}$ \\
Intron IV & $0.4 \mathrm{~kb}$ & $1.3 \mathrm{~kb}$ \\
Exon 5 & $381 \mathrm{bp}$ & $381 \mathrm{bp}$ \\
\hline
\end{tabular}




\section{Figure Legends}

Figure 1. Nucleotide and deduced amino acid sequence of the Hh Kiss1r-2. Numbers indicate the nucleotide position starting at the A of the initial ATG codon (top line, bold) and the amino acid positions starting at the initial methionine ( $\mathrm{M}$, bottom line). The seven transmembrane domains (TMDs) are underlined and numbered. The triangles indicate the location the intron-exon boundaries. An asterisk indicates the termination codon.

Figure 2. Amino acid alignment of Atlantic halibut (Hh $\underline{\text { Kiss } 1 r-2})$ with selected fish $\underline{\text { Kiss } 1 r-2}$ sequences: zebrafish-A (ZfA, $\underline{\mathbf{A B V 4 4 6 1 2}}$ ), Atlantic croaker (Ac, $\underline{\mathbf{A B C 7 5 1 0 1}})$, cobia (Co, $\underline{\text { ABG82165 }}$ ), grey mullet (Gm, $\underline{\text { ABG76790 }}$ ), Nile tilapia (Nt, $\underline{\text { BAD34454) }}$ and Senegalese sole (Ss, $\underline{\mathbf{E U 1 3 6 7 1 0}})$. Asterisks indicate a perfect match among all aligned sequences whereas dots represent conservative replacements: (.) indicates conserved, and (:) highly conserved. Numbers at the end of each line refer to the amino acid position. The signal peptide and transmembrane domains (TMDs) are boxed. The putative $N$-glycosylation sites are underlined, serine kinase filled by black arrowheads, theonine sites filled by black diamond and tyrosine kinase, filled by black circles. Numbers indicate amino acid number.

Figure 3. Synteny of $\underline{\text { Kiss } 1 r-2}$ in teleost fish. Genomic organization of the zebrafish, pufferfish, fugu, medaka and three-spined stickleback $\underline{\text { Kiss } 1 r-2}$ are from Ensembl (chromosomes 2, 15, scaffold_80, 17 and group III, respectively). The Atlantic halibut sequence is from a $92 \mathrm{~kb} \mathrm{BAC}$ clone that contains only partial atp6v0b and $\underline{o d f} 2 L$ sequences. Abbreviations: b4galt2, $\beta$-1,4-galactosyltransferase 2; atp6v0b, V-type proton ATPase $21 \mathrm{kDa}$ proteolipid subunit; hyp. prot., conserved hypothetical protein; miRNA, three predicted 
miRNA (miR-23a, miR-27a, miR-24); b0s7g2, novel kinesin-like protein; atp5L, ATP synthase subunit g; rabL5, rab-like protein 5; odf2L, sperm tail outer dense fiber protein 2like.

Figure 4. Phylogenetic and evolutionary relationships of vertebrate Kiss1r sequences. (A) Unrooted phylogenetic tree constructed using the neighbour-joining method of Mega version

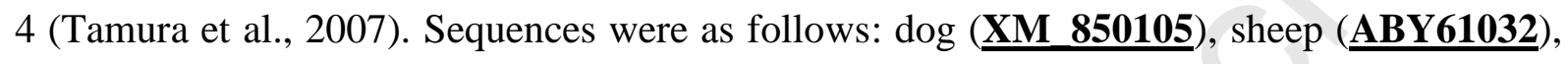

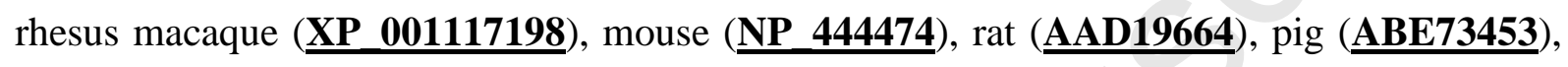
human ( $\underline{\mathbf{A A K 8 3 2 3 5}}$ ), chimpanzee ( $\underline{\mathbf{X R} \text { 020820 }})$, opossum ( $\underline{\text { XM 001374715)}}$, platypus (platypus-1, Ultra_266:390150;395924; platypus-1B, Contig 15629:1100:6789), clawed frog (clawed frog-1A, EU85678; clawed frog-1B, $\underline{\mathbf{E U 8 5 3 6 7 9}}$; clawed frog-2, $\underline{\mathbf{E U 8 5 3 6 8 0}}$ ), medaka (medaka-1, Chromosome 9:4480521:4500733; medaka-2, Chromosome $\underline{\text { 17:29839761:29855706}}$ ); zebrafish (zebrafish_A, $\underline{\text { ABV44612 }}$; zebrafish_B, ABV44613 $)$;

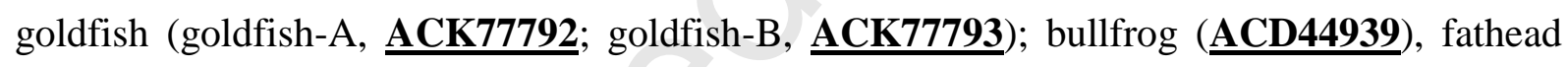

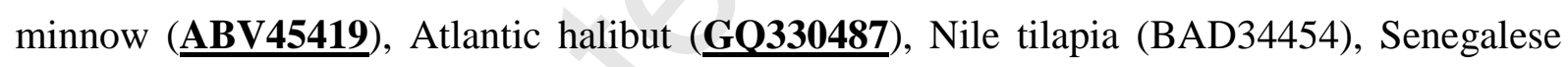

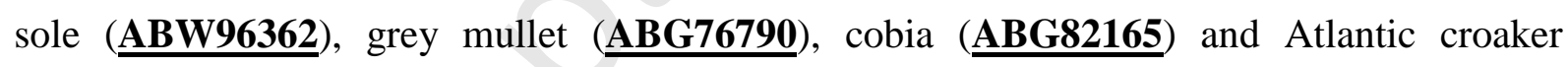
( $\underline{\text { ABC75101)}}$. Three-spined stickleback, fugu, pufferfish, lesser hedgehog, Anole lizard, pika, guinea pig, bushbaby, dolphin, megabat, microbat, kangaroo rat, orangutan, gorilla and mouse lemur were obtained from public databases (Ensembl). (B) $\underline{\text { Kiss } 1 r}$ evolution in vertebrates as deduced from the information available so far. $\mathrm{D}=$ duplication.

Figure 5. Conserved upstream regions in fish $\underline{\text { Kiss } 1 r-2}$. The positions of six conserved regions detected by Meme are indicated relative to the ATG start codon of Kiss1r-2. Black boxes correspond to sequences similar to [CT]GTTGCTAGGAGACCC, which has similarity 
to the MIF-1 binding site; diagonally striped boxes correspond to [CT]TCCTC[TG]CTCTGCCC; checkered boxes correspond to $\mathrm{A}[\mathrm{AG}][\mathrm{GA}][\mathrm{AG}] \mathrm{AGCTG}[\mathrm{CT}][\mathrm{AG}][\mathrm{GA}][\mathrm{GT}] \mathrm{TG}$; horizontally striped boxes correspond to T[GT]TGTCTCTTT; grey boxes to $\mathrm{AGG}[\mathrm{GT}] \mathrm{CA}[\mathrm{CG}] \mathrm{ACA}[\mathrm{GC}][\mathrm{GA}][\mathrm{AC}] \mathrm{C}[\mathrm{TC}] \mathrm{C}$, which has similarity to the estrogen receptor binding site; white boxes to CAATCAT[GT]C[CT]GTA[GT]CCC[AT]C[GT]TG[CT]A[TA]T[GC]AG.

Figure 6. Essential biometry and gonadal development in Atlantic halibut. Total length (TL) (A) and Weight (B) for four different year old-classes (1, 3, 5 and 7 years old). Data as mean \pm S.E.M $(\mathrm{n}=4-8)$. (C) Microscopic characteristic of the different stages of gonadal maturation in males (a-d) and females (e-h) of Atlantic halibut. Spg = Spermatogonia, Spc = Spermatocyte, $\mathrm{Spd}=$ Spermatid, $\mathrm{Spz}=$ Spermatozoa . Oo = Oocyte, Oc = Ovarian cavity .

Figure 7. Tissue distribution of Hh $\underline{\text { Kiss } 1 r-2}$ at two developmental stages, early puberty (three year old) and mature fish (seven year old). Agarose gels show RT-PCR products obtained from, brain (BR), ovary (OV), testis (TS), liver (LV), muscle (MS), stomach (ST), heart (HT), intestine (IT) and kidney (KD). $\underline{\beta \text {-actin }}$ was included for verifying the presence of mRNA in each sample. No-template control (NTC) was used as a negative control.

Figure 8. Hh $\underline{\text { Kiss } 1 r \text {-2 }}$ expression in (A) brain and (B) gonads from different year-class fish as determined by qPCR. Results were normalized against $\underline{\beta \text {-actin }}$ RNA levels and corrected for amplification efficiency. The expression level in brain of 1 year-old fish was arbitrarily set at 1. Results in B are expressed as fold-change relative to the reference expression level in 
panel $\mathrm{A}$ in order to compare relative expression between the two tissues. Data are means \pm S.E.M $(n=4-7)$. N.d, not detected. 
ATGTTTTCCTCCGAGGAACCGTGGAACTCCACCGAGCAGGTCTGGCTCAATGGCTCGGAG 60 $\begin{array}{lllllllllllllllllllllllllllll}M & F & S & S & E & E & P & W & N & S & T & E & \& & V & W & L & N & G & S & E\end{array}$

AGGGCGAACTTCTCCCTGGGAAGACGCGGGAGCGACGACCACGAGGAGGAGGAGGACGgG 120 $\begin{array}{lllllllllllllllllllll}R & A & N & F & S & L & G & R & R & G & S & D & D & H & E & E & E & E & D & G\end{array}$

GATCAGCACCCCTTCCTCACAGACGCCTGGCTGGTGCCCCTCTTGTTCTCCCTCATCATG 180

\begin{tabular}{llllllllllllllllllll}
$D$ & $Q$ & $H$ & $P$ & $F$ & $L$ & $T$ & $D$ & $A$ & $W$ & $L$ & $V$ & $P$ & $L$ & $L$ & $F$ & $S$ & $L$ & $I$ & $M$ \\
\hline
\end{tabular}

CTGGTGGGTGTGGTGGGCAACTCGCTGGTCATCTATGTCATCTCCAAACACAGGCAGATG 240 $\begin{array}{lllllllllllllllllllll}\mathrm{L} & \mathrm{V} & \mathrm{G} & \mathrm{V} & \mathrm{V} & \mathrm{G} & \mathrm{N} & \mathrm{S} & \mathrm{L} & \mathrm{V} & \mathrm{I} & \mathrm{Y} & \mathrm{V} & \mathrm{I} & \mathrm{S} & \mathrm{K} & \mathrm{H} & \mathrm{R} & \mathrm{Q} & \mathrm{M}\end{array}$

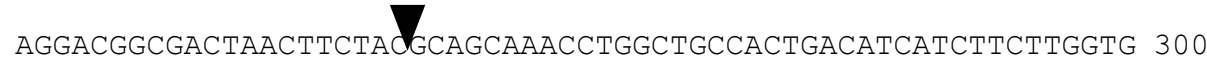
\begin{tabular}{llllllllllllllllllll}
$R$ & $T$ & $A$ & $T$ & $N$ & $F$ & $Y$ & $A$ & $A$ & $N$ & $L$ & $A$ & $A$ & $T$ & $D$ & $I$ & $I$ & $F$ & $L$ & $V$ \\
\hline
\end{tabular}

TGCTGCGTCCCCTTCACTGCCACCCTCTACCCTCTCCCCGGATGGATCTTTGGCAACTTC 360 $\begin{array}{llllllllllllllllllll}\mathrm{C} & \mathrm{C} & \mathrm{V} & \mathrm{P} & \mathrm{F} & \mathrm{T} & \mathrm{A} & \mathrm{T} & \mathrm{L} & \mathrm{Y} & \mathrm{P} & \mathrm{L} & \mathrm{P} & \mathrm{G} & \mathrm{W} & \mathrm{I} & \mathrm{F} & \mathrm{G} & \mathrm{N} & \mathrm{F}\end{array}$ ATGTGCAAGTtTGTCGCCTtTCtACAgCAgGTGACGGTCCAGGCCACTTGTATCACCCTG 420

$\begin{array}{llllllllllllllllllll}M & C & K & F & V & A & F & L & Q & Q & V & T & V & Q & A & T & C & I & T & L \\ \end{array}$

ACTGCCATGAGTGGAGACCGCTGTTACATCACCATCTACCCTCTGAAATCCCTCCGCCAC 480 $\begin{array}{lllllllllllllllllllllll}\mathrm{T} & \mathrm{A} & \mathrm{M} & \mathrm{S} & \mathrm{G} & \mathrm{D} & \mathrm{R} & \mathrm{C} & \mathrm{Y} & \mathrm{I} & \mathrm{T} & \mathrm{I} & \mathrm{Y} & \mathrm{P} & \mathrm{L} & \mathrm{K} & \mathrm{S} & \mathrm{L} & \mathrm{R} & \mathrm{H}\end{array}$

CGCACCCCGAGAgTAGCCATGATCGTCAGCATCTGCATtTGGATCGGCTCCTTCATCCTG 540 \begin{tabular}{llllllllllllllllllll}
$R$ & $\mathrm{~T}$ & $\mathrm{P}$ & $\mathrm{R}$ & $\mathrm{V}$ & $\mathrm{A}$ & $\mathrm{M}$ & $\mathrm{I}$ & $\mathrm{V}$ & $\mathrm{S}$ & $\mathrm{I}$ & $\mathrm{C}$ & $\mathrm{I}$ & $\mathrm{W}$ & $\mathrm{I}$ & $\mathrm{G}$ & $\mathrm{S}$ & $\mathrm{F}$ & $\mathrm{I}$ & $\mathrm{L}$ \\
\hline
\end{tabular}

TCCACCCCCATTTTGATGTACCAGCGCATAGAGGAGGGTTACTGGTACGGTCCCAGACAA 600 $\begin{array}{llllllllllllllllllll}\mathrm{S} & \mathrm{T} & \mathrm{P} & \mathrm{I} & \mathrm{L} & \mathrm{M} & \mathrm{Y} & \mathrm{Q} & \mathrm{R} & \mathrm{I} & \mathrm{E} & \mathrm{E} & \mathrm{G} & \mathrm{Y} & \mathrm{W} & \mathrm{Y} & \mathrm{G} & \mathrm{P} & \mathrm{R} & \mathrm{Q}\end{array}$

TACTGCATGGAGAGATTTCCCTCTAAAACACACGAGAGGGCTTTCATCCTCTACCAGTTC 660 $\begin{array}{llllllllllllllllllll}Y & C & M & E & R & F & P & S & K & T & H & E & R & A & F & I & L & Y & Q & F\end{array}$

ATTGCTGCCTACCTGCTGCCCGTCCTCACCATCTCCTTCTGCTACACTCTGATGGTGAAG 720 $\begin{array}{llllllllllllllllllllll}\text { I } & \text { A } & \text { A } & \text { Y } & \text { L } & \text { L } & \text { P } & \text { V } & \text { L } & \text { T } & \text { I } & \text { S } & \text { F } & \text { C } & \text { Y } & \text { T } & \text { L } & \text { M } & \text { V } & \text { K } \\ \text { AGGGTGGGTCAGCCCACTGTGGAGCCGGTGGACAACAACTACCAGGTAAACCTCCTGTCT } & 780\end{array}$ $\begin{array}{llllllllllllllllllll}R & V & G & Q & P & T & V & E & P & V & D & N & N & Y & Q & V & N & L & L & S\end{array}$

GAGAGAACGTTAAGTATCAGGAGCAAAGTGTCCAGGATGGTGGTTGTGATTGTCCTCCTC 840 $\begin{array}{llllllllllllllllllll}\mathrm{E} & \mathrm{R} & \mathrm{T} & \mathrm{L} & \mathrm{S} & \mathrm{I} & \mathrm{R} & \mathrm{S} & \mathrm{K} & \mathrm{V} & \mathrm{S} & \mathrm{R} & \mathrm{M} & \mathrm{V} & \mathrm{V} & \mathrm{V} & \mathrm{I} & \mathrm{V} & \mathrm{L} & \mathrm{L} \\ \end{array}$

TTCGCCATCTGCTGGGGACCCATCCAGATCTTCGTCCTCTTCCAGTCGTTCCATCCAAAC 900 $\begin{array}{lllllllllllllllllllll} & F & A & I & C & W & G & P & I & Q & I & F & V & L & F & Q & S & F & H & P & N\end{array}$

TACCGACCAAACTACGTCACGTACAAGATCAAGACGTGGGCCAACTGCATGTCGTACGCC 960 $\begin{array}{llllllllllllllllllllll}\mathrm{Y} & \mathrm{R} & \mathrm{P} & \mathrm{N} & \mathrm{Y} & \mathrm{V} & \mathrm{T} & \mathrm{Y} & \mathrm{K} & \mathrm{I} & \mathrm{K} & \mathrm{T} & \mathrm{W} & \mathrm{A} & \mathrm{N} & \mathrm{C} & & \mathrm{M} & \mathrm{S} & \mathrm{Y} & \mathrm{A}\end{array}$

AACTCCTCCGTCAACCCCATCGTTTACGGATTCATGGGAGCCAGCTTCCAAAAGTCCTTC 1020 $\begin{array}{lllllllllllllllllllll}\mathrm{N} & \mathrm{S} & \mathrm{S} & \mathrm{V} & \mathrm{N} & \mathrm{P} & \mathrm{I} & \mathrm{V} & \mathrm{Y} & \mathrm{G} & \mathrm{F} & \mathrm{M} & \mathrm{G} & \mathrm{A} & \mathrm{S} & \mathrm{F} & \mathrm{Q} & \mathrm{K} & \mathrm{S} & \mathrm{F}\end{array}$

AGGAAAACCTTCCCCTTCCTGTTCAAGCACAAAGTCAGAGATAGCAGCATGGCTTCAAGG 1080 $\begin{array}{llllllllllllllllllll}R & K & T & F & P & F & L & F & K & H & K & V & R & D & S & S & M & A & S & R\end{array}$

ACCGGCAACGCCGAGATCAAGTTTGTCGCGGCAGAGGAAGGCAACAATAATAACGCAGTG 1140 $\begin{array}{llllllllllllllllllll}T & G & N & A & E & I & K & F & V & A & A & E & E & G & N & N & N & N & A & V\end{array}$

AATTGA 1146

$\mathrm{N}$

Figure 1. Mechaly, et al., 2009 
ZfA MFSGED-WNSSE--LLNGS-FRNSSME-------DSEDGE-HPFLTPAWEVPLFFSLIM 47

AC MYSTKELWNSTEQIWFNGS-EANLSLGRRGND---EEEEGQQHPFLTPAWLVPLFFALIM 56

Co MYSTKELWNSTEQVWINGS-GTNFSLGRRGND---EEEEGQQHPFLTPAWLVPLFFSLIM 56

Gm MHSSEEPWNSSEHVWVNGS-EANFSLGRRRVDEEKEEEEGGQHPFLTPAWLVPLFFSLIM 59

Nt MYSSEELWNSTEQVWINGS-GTNESLGRHEDD---EEEEGDKHPFFTPAWLVPLFFSLIM 56

SS MYSSKEPWNSTDRVWINGS-RVNVSLERHGDSD--EEDEGDQHPFLTPAWLVPLFFSLIM 57

Hh MFSSEEPWNSTEQVWLNGSERANESLGRRGSDDHEEEEDGDQHPFLTPAWLVPLLFSLIM 60

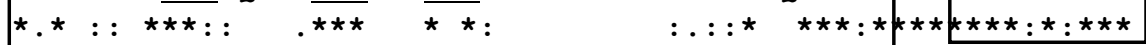

TMD2

ZfA LVGLIGNSLVIPVISKHRQMRTATNFYIANLAATDIIFLLCCVPFTA PLYPLPGWIFGDF 107

AC LVGLVGNSRVIYVISKHRQMRTATNFYIANLAATDIIFLVCCVPFTA PLYPLPGWIFGNF 116

Co LVGLVGNSRVIYVISKHRQMRTATNFYIANLAATDI IFLVCCVPFTA PLYPLPGWIFGNF 116

Gm LVGLVGNSLVIYVISKHRQMRTATNFYIANLAATDI IFLVCCVPFTA PLYPLPGWIFGNF 119

Nt LVGLVGNSLVIYVISKHRQMRTATNFYIANLAATDI IFLVCCVPFTA LYYPLPGWIFGNF 116

Ss LVGLVGNSLVIYVISKHRQMRTATNFYIANLAATDIIFLVCCVPFTA PLYPLPGWIFGNF 117

Hh LVGVVGNSLVIYVISKHRQMRTATNFYAANLAATDIIFLVCCVPFTA PLYPLPGWIFGNF 120

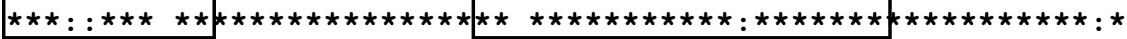

TMD3

TMD4

ZfA MCKFVAFLQQVTVQATCITLTAMSGDRCYVTVYPLKSLHHRIPRVAMIVSICIWIGSFIL 167

AC MCKFVAFLQQVTVQATCITLTAMSGDRCYVTVYPLKSLRHRTPRVAMIVSICIWIGSFIL 176

CO MCKFVAFLQQVTVQATCITLTAMSGDRCYVTVYPLKSLRHRTPRVAMIVSVCIWIGSFIL 176

Gm MCKFVAFLQQVTVQATCITLTAMSGDRCYVTVYPLKSLRHRTPKVAMIVSVCIWIGSFIL 179

Nt MCKFVAFLQQVTVQATCITLTAMSGDRCYVTVYPLKSLRHRTPKVAMIVSICIWIGSFVI 176

Ss MCKFVAFLQQVTVQATCITLTAMSGDRCYVTVYPLKSLRHRTPRVAMIVSLCIWIGSFIL 177

Hh MCKFVAFLQQVTVQATCITLTAMSGDRCYITIYPLKSLRHRTPRVAMIVSICIWIGSFIL 180

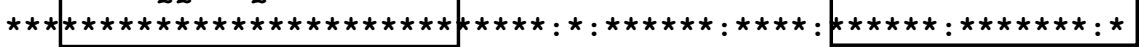

TMD5

ZfA SIPIFLYQRLEDGYWYGPRKYCMERFPSKTHEKAFILYQFIAVYLLPVITISFCFSFMLK 227

AC STPILVYQRIEDGYWYGPRQYCMERFPSKTHERAFILYQFIAAYLLPVLTISFC TTIMVK 236

CO STPILMY QRIEEGYWYGPRQYCMERFPSKTHERAFILYQFIAAYLLPVLTISFC TTLMVK 236

Gm STPILMYRIEEGYWYGPRQYCMERFPSKTHER AFILYQFIAAYLLPVLTITFC TTLMV 239

Nt STPILMYQRIEEGYWYGPRQYCMERFPSKTHERAFILYQFIAAYLLPVLTISFC FTLMVK 236

Ss STPILMYQRIEDGYWYGPRQYCMERFPSKTHEOAFILYQFIAAYLLPVLTISFC FTLMVK 237

Hh STPILMYQRIEEGYWYGPRQYCMERFPSKTHERAFILYQFIAAYLLPVLTISFC TTLMVK 240

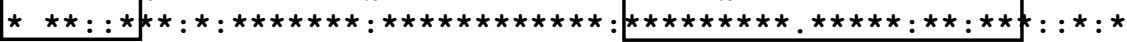

\section{TMD6}

ZfA RVGQASVEPVDNNHQVHLLSERTISIRSKISKMVVVIVVLFTICWGPIQIFVLFQSFYPN 287

AC RVGQPTVEPVDNNYQVNLLSERTISIRSKVPKMVVVIVLLFAICWGPIQIFAL FQSFYPN 296

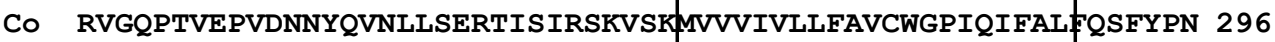

Gm RVGQPTVEPVDNNYQVNLLSERTISIRSKVSKMVVVIVLLFAVCWGPIQIFVLFQSFYPN 299

Nt RVGQPTVEPVDNNYQVNLLSERTISIRSKVSKUVVVIVLLFAICWGPIQIFVL \&QSFYPN 296

SS RVGQPTVEPVDNNYQVNLLSERTISIRSKVSKMVVVIVLLFTICWGPIQIFVL FQSFHPN 297

Hh RVGQPTVEPVDNNYQVNLLSERTLSIRSKVSRMVVVIVLLFAICWGPIQIFVL FQSFHPN 300

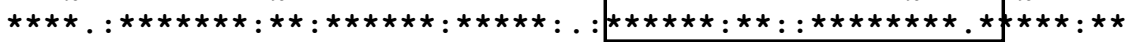

TMD7

ZfA FKANYATYKIKTWANCMSYANSSTNPIVYGFMGASFRKSFRKTFPFLFRHKVRDSSVASR 347

AC YQHNYATYKIKTWANCMSYANSSVNPIVYGFMGATFOKSFRKTFPFLFKHKVRDSSMASR 356

Co YQHNYATYKIKTWANCMSYANSSVNPIVYGFMGASFQKSFRKTFPFLFKHKVRDSSMASR 356

Gm YQPNYATYKIKTWANCMSYANSSVNPIVYGFMGASFQKSFRKTFPFLFKHKVRDSSMASR 359

Nt YQPNYATYKIKIWANCMSYANSSVNPIVYGFMGASFQKSFRKTFPFLFKHKVRDSSMASR 356

Ss YRPNYVTYKIKIWANCMSYANSSVNPIVYGFMGASFQKSFRKTFPFLFKHKVRDSSMASR 357

Hh YRPNYVTYKIKTWANCMSYANSSVNPIVYGFMGASFOKSFRKTFPFLFKHKVRDSSMASR 360

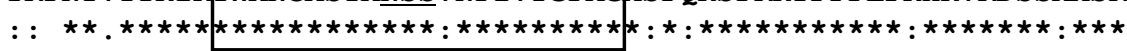

ZfA TANAEIKL----------- 355

AC TANAEIKFVAAEEGNNNNAMN 377

CO TANAEIKFVAAEEGNNNNAMN 377

Gm TANAEIKFVAAEEGNNNNAVN 380

Nt TANAEIKFVAAEEGNNNNAVN 377

SS TANAEIKFVAAEEGNNNNAMN 378

Hh TGNAEIKFVAAEEGNNNNAVN 381 $\star . \star \star \star \star \star *$. 
Zebrafish

31.4

31.7

$32.0 \mathrm{Mb}$

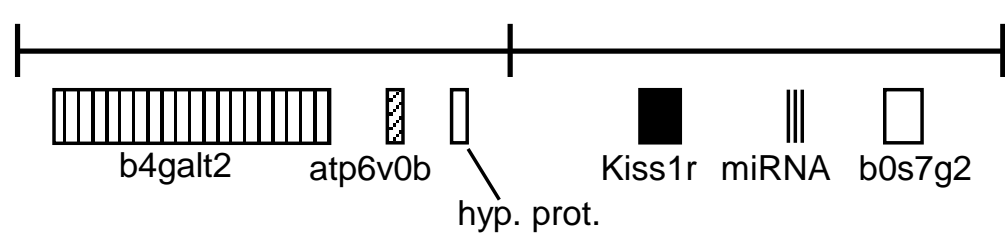

Pufferfish

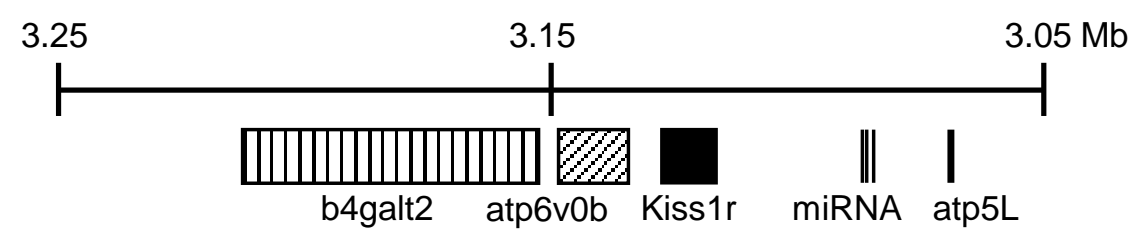

Fugu

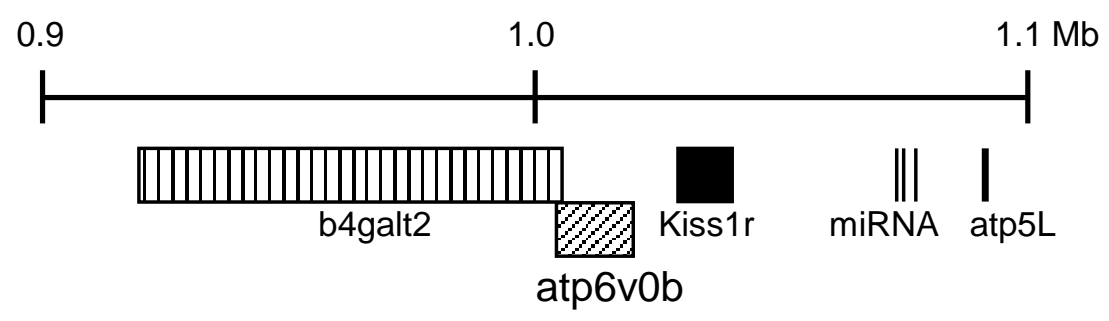

Medaka

30.1

29.9

$29.7 \mathrm{Mb}$
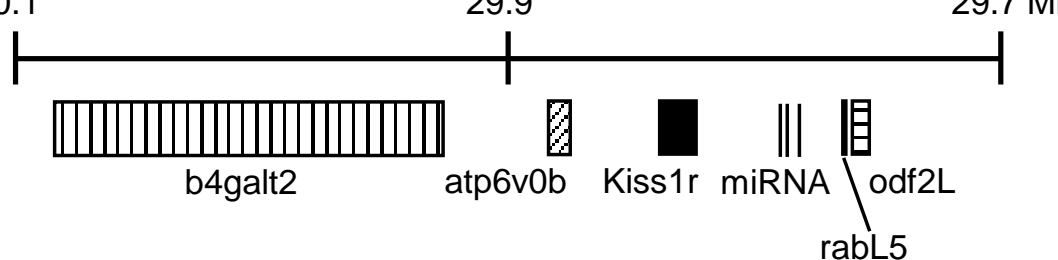

T. stickleback

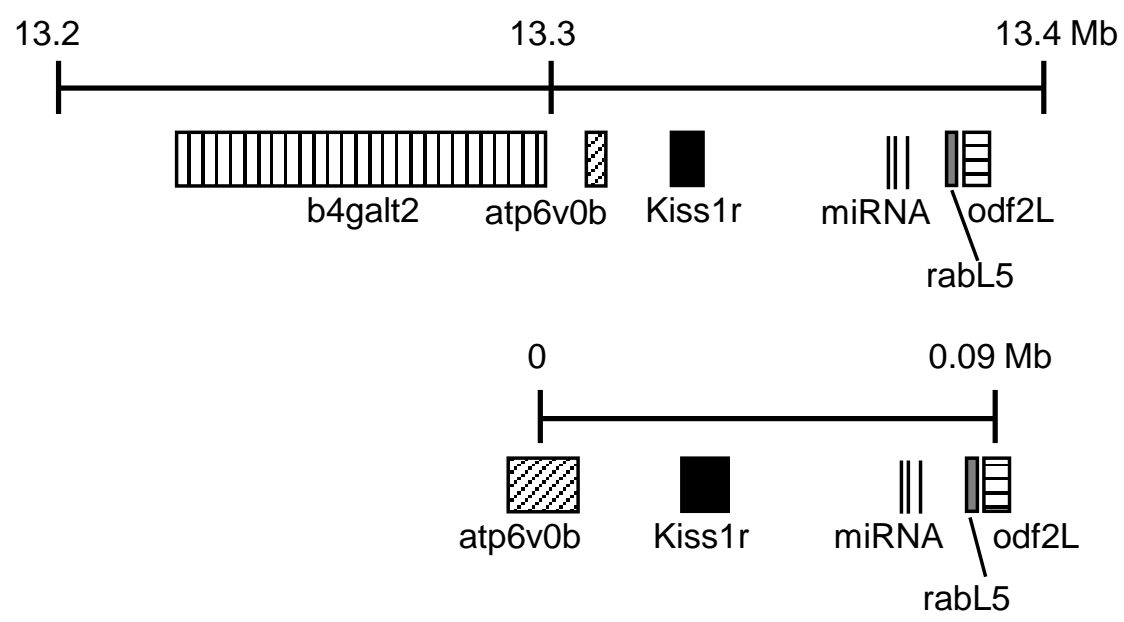



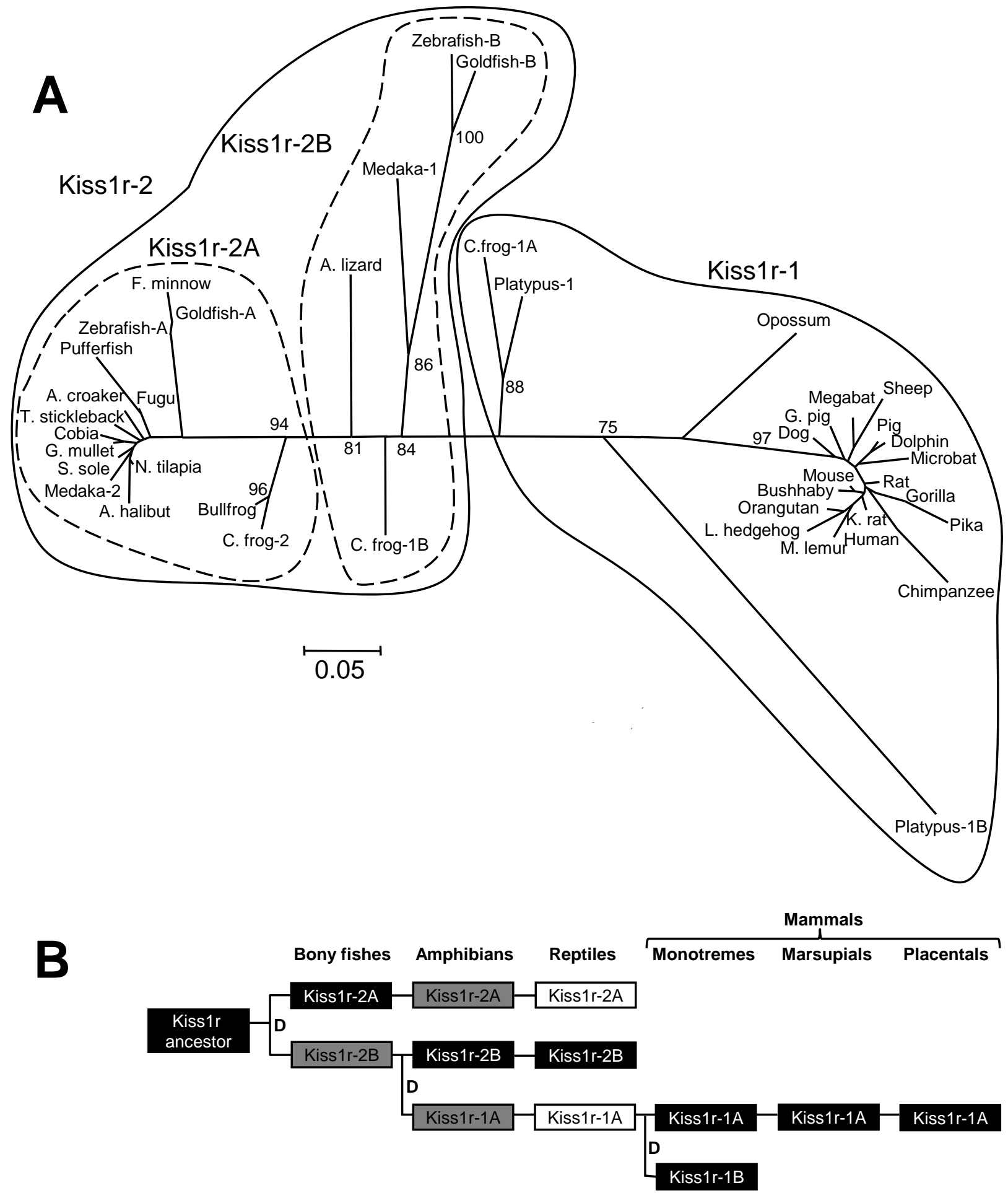

Gene present

Gene present only in some species

Gene not detected 
Zebrafish

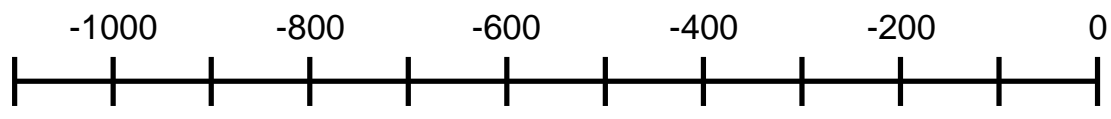

Medaka

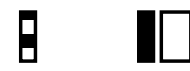

[

目目 I

T. stickleback

Fugu

Pufferfish

A. halibut

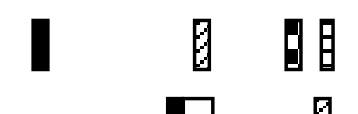

目

１目

口目

日

口目

D

日 $\square$ 目

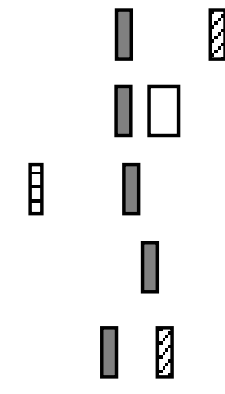

Figure 5. Mechaly, et al., 2009 
A

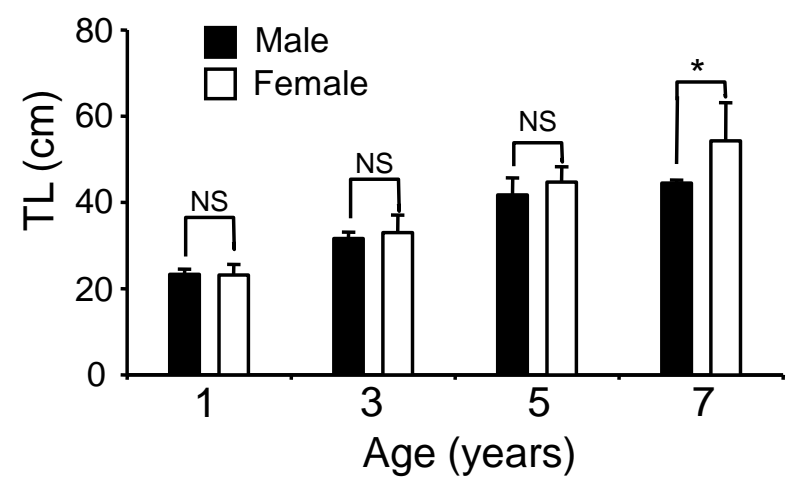

C
B

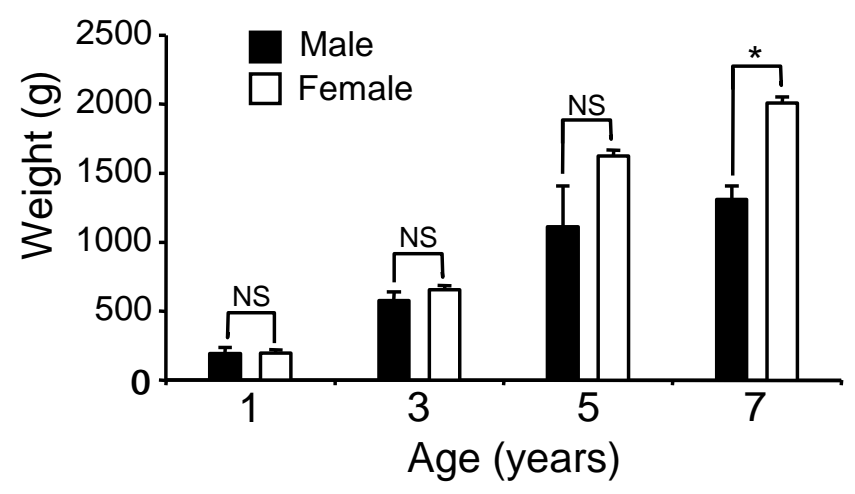

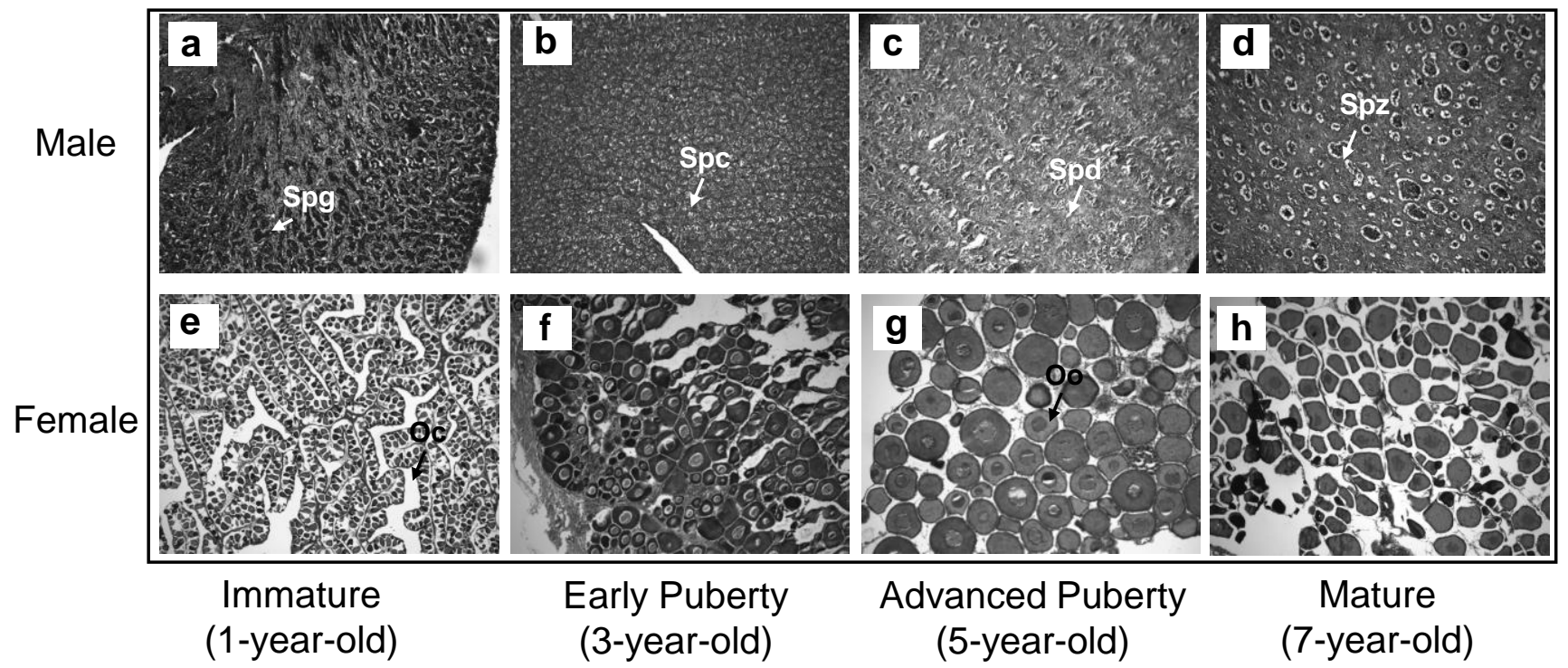


Male

Female

BR TS LV MS ST HT IT KD NTC BR OV LV MS ST HT IT KD NTC

Early puberty

(3-year-old)

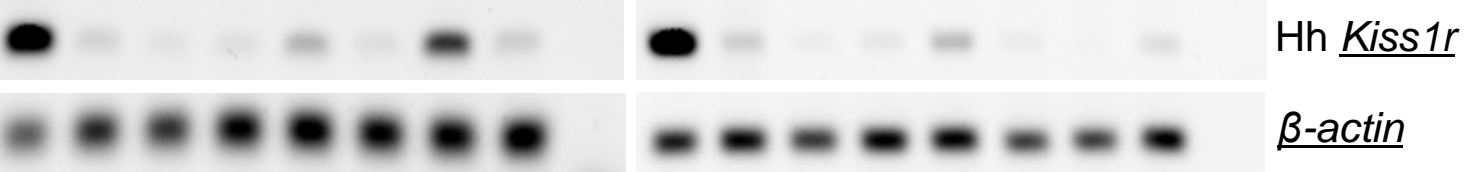

Mature
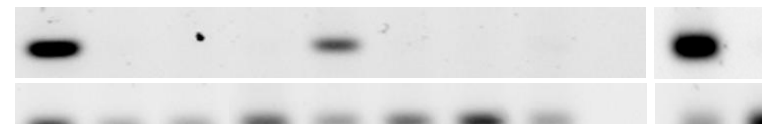

Hh $\underline{\text { Kiss1r }}$

(7-year-old)

$\beta$-actin 


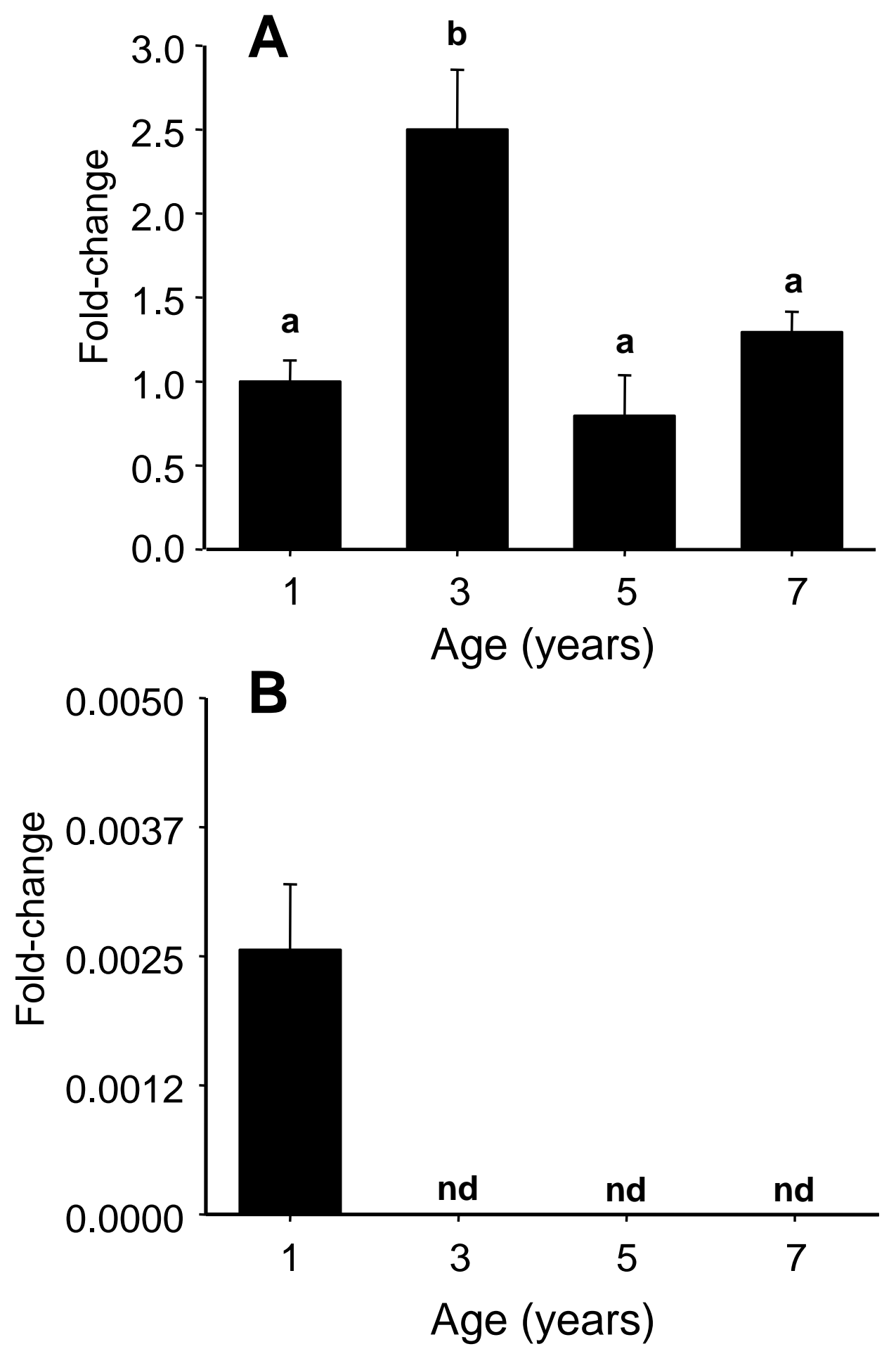

Figure 8. Mechaly, et al., 2009 